Volume 121

Issue 3 Dickinson Law Review - Volume 121,

2016-2017

$1-1-2017$

\title{
Expanding General Personal Jurisdiction Over Transnational Corporations For Federal Causes of Action
}

Gwynne L. Skinner

Follow this and additional works at: https://ideas.dickinsonlaw.psu.edu/dlra

\section{Recommended Citation}

Gwynne L. Skinner, Expanding General Personal Jurisdiction Over Transnational Corporations For Federal Causes of Action, 121 Dick. L. REv. 617 (2017).

Available at: https://ideas.dickinsonlaw.psu.edu/dlra/vol121/iss3/2

This Article is brought to you for free and open access by the Law Reviews at Dickinson Law IDEAS. It has been accepted for inclusion in Dickinson Law Review by an authorized editor of Dickinson Law IDEAS. For more information, please contactlja10@psu.edu. 


\title{
Articles
}

\section{Expanding General Personal Jurisdiction Over Transnational Corporations For Federal Causes of Action}

\author{
Gwynne L. Skinner*
}

\begin{abstract}
This article advocates for expanding general personal jurisdiction over transnational corporations so that where Congress has provided for a cause of action for extraterritorial violations of law, such as in the area of human rights and terrorism, victims have an opportunity to obtain a remedy. The article discusses the history of general personal jurisdiction over corporations, the recent decisions of Goodyear Dunlop Tires Operations, S.A. v. Brown, and Daimler AG v. Bauman and their impact on victims' ability to obtain a remedy for extraterritorial business-related human rights violations, and recommends that Congress enact a statute requiring that transnational corporations doing business in the United

* Associate Professor of Law, Willamette University College of Law. The author would like to thank participants at the ASIL Research Forum and the Second Annual Business and Human Rights Scholars Conference for their helpful feedback, especially Perry Bechky and Connie De La Vega. Thanks also to my colleague, Professor Aaron Simowitz, for his very helpful and detailed feedback on earlier versions of the article. Special thanks to my research assistants, Kristine Osuna and Kathryn Pawlick, for their invaluable assistance.
\end{abstract}


States consent to the general personal jurisdiction of U.S. courts in those instances where Congress has provided a cause of action for claims that arise extraterritorially.

\section{Table of Contents}

INTRODUCTION 619

I. EVOLUTION OF U.S. COURTS' GeNERAL PERSONAL JURISDICTION OVER TRANSNATIONAL CORPORATIONS.

A. Early U.S. History of General Jurisdiction Over Corporations.... 626

B. International Shoe

C. General Personal Jurisdiction Over Transnational

Corporations Post-International Shoe

II. MODERN DEVELOPMENT OF HUMAN RightS Claims IN THE UNITED STATES UNDER THE ALIEN TORT STATUTE, AND COURTS' ASSERTION OF GENERAL PERSONAL JURISDICTION OVER TRANSNATIONAL CORPORATIONS INVOLVED IN SUCH CLAIMS 634

A. The Modern Development of the ATS 634

B. Before Goodyear and Daimler, Courts Often Asserted General Personal Jurisdiction Over TNCs in ATS Cases.

III. THE SEA CHANGE-GOODYEAR TO DAIMLER …………............................639

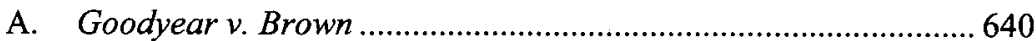

B. The Nicastro Decision and Specific Personal Jurisdiction............ 642

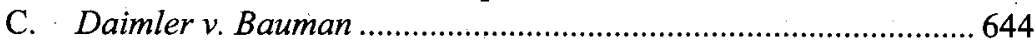

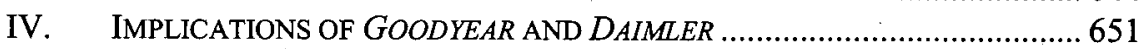

A. Goodyear and Daimler's Effect on Human Rights Cases............. 651

B. Goodyear's and Daimler's Effect on Other Human-Rights

Related Claims

C. Narrow Jurisdiction Over TNCs Stands in Stark Contrast to Transient, or "Tag," Jurisdiction over Individuals.

V. MORE EXPANSIVE PERSONAL JURISDICTION OVER TNCS IS REASONABLE AND FAIR

A. Harmed Individuals Often Have a Difficult Time Accessing Remedies in Host Countries for Human Rights Violations, Thereby Absorbing All the Costs While TNCs Benefit.

B. Current Jurisdictional Rules do not Reflect How TNCs are Structured and Operate, Allowing TNCs that Violate International Human Rights Norms to Escape any Meaningful Accountability

VI. THE UNITED STATES SHOULD REQUIRE TNCS DOING BUSINESS IN THE UNITED STATES to CONSENT TO GENERAL PERSONAL JURISDICTION FOR FEDERAL CAUSES OF ACTION.

A. Congress Should Enact a Statute Requiring All TNCs that.Do Business in the United States to Consent to Personal Jurisdiction Where Congress Has Provided a Claim for Extraterritorial Conduct. 
1. What Constitutes "Doing Business?"'..................................6 676

2. Expanded Jurisdiction is Not Unprecedented ........................677

B. A Statutory Enactment Would Provide for an Even Playing

Field for U.S. Corporations.................................................... 678

C. Comity and Foreign Relations are not Substantial

Impediments.

CONCLUSION

\section{INTRODUCTION}

In the recent cases of Goodyear Dunlop Tires Operations, S.A. v. Brown, ${ }^{1}$ and Daimler $A G$ v. Bauman, ${ }^{2}$ the U.S. Supreme Court created a sea change by severely limiting general personal jurisdiction ${ }^{3}$ over transnational corporations (TNCs). ${ }^{4}$ For decades prior to these cases, most lower courts relied on the 1945 case of International Shoe Co. $v$. Washington $^{5}$ in asserting general personal jurisdiction over a foreign corporation whenever the defendant corporation had engaged in "sufficiently substantial continuous activity" in the U.S. state where the claim was brought (forum state), often characterizing such as "continuous and systematic" activity. In Goodyear and Daimler, the

1. Goodyear Dunlop Tires Operations, S.A. v. Brown, 564 U.S. 915 (2011).

2. Daimler AG v. Bauman, 134 S. Ct. 746 (2014).

3. General personal jurisdiction exists where a defendant has sufficiently substantial contacts with a state to allow that state's courts, or a federal court sitting in that state, to assert jurisdiction over the defendant, even where the cause of action is unrelated to a defendant's contacts with the state. Arthur T. von Mehren \& Donald T. Trautman, Jurisdiction to Adjudicate: A Suggested Analysis, 79 HARV. L. REv. 1121, 1172,1179 (1966); Goodyear, 564 U.S. at 924. Specific jurisdiction exists where the defendant has sufficient contacts with the State, and the cause of action arises from, or is related to, those contacts. Goodyear, 564 U.S. at 924 . This Article primarily concerns general personal jurisdiction, but does discuss briefly, infra Part II.B, the narrowing of specific jurisdiction over corporations.

4. I adopt the definition of a TNC set forth by United Nations Conference on Trade and Development: "Transnational corporations (TNCs) are incorporated or unincorporated enterprises comprising parent enterprises and their foreign affiliates. A parent enterprise is defined as an enterprise that controls assets of other entities in countries other than its home country, usually by owning a certain equity capital stake." Transnational corporations (TNC), U.N. CONF. ON TRADE AND DEV., http://unctad. org/en/Pages/DIAE/Transnational-corporations-(TNC). aspx (last visited October 17, 2016). The term should be considered synonymous with transnational businesses or multinational corporations (MNCs).

5. Int'l Shoe Co. v. Washington, 326 U.S. 310 (1945).

6. Id. at 321 . The Court also used the phrase "activity so substantial and of such a nature to justify" general personal jurisdiction. Id. at 318.

7. Goodyear, 564 U.S. at 925 . See also lower cases so holding, infra Part I.C, and noting that many courts continued to use the term "systematic and continuous business," even though International Shoe used the term "so substantial and of such a nature to justify" general personal jurisdiction. Int'l Shoe, 326 U.S. at 318 (emphasis added). 
Court held that even where a corporation conducts continuous and systematic business activity in the United States, a U.S. court cannot assert general personal jurisdiction over it consistent with the Due Process Clause unless the corporation is essentially "at home" in the forum state. ${ }^{8}$ Under Daimler, in nearly all circumstances, this will mean the corporation must be headquartered or incorporated in the forum state. $^{9}$

Among other potential implications of this jurisdictional limitation, ${ }^{10}$ it will severely impact the ability of victims of extraterritorial business-related human rights violations to seek a remedy for the violations. ${ }^{11}$ Because of Goodyear and Daimler, victims of extraterritorial business-related human rights violations will find it nearly impossible to seek a remedy in the United States against a TNC involved in the violation if the TNC is not headquartered or incorporated in the United States, even though it may well be doing significant business in the United States. This is true even where Congress has seen fit to provide for a cause of action over these extraterritorial claims, such as through the Alien Tort Statute (ATS), ${ }^{12}$ the Anti-Terrorism Act (ATA), ${ }^{13}$ (2014)

8. Goodyear, 564 U.S. at 918-19; Daimler AG v. Bauman, 134 S. Ct. 746, 751

9. Daimler, $134 \mathrm{~S}$. Ct. at 761 . The Court does note that there might be an otherwise exceptional circumstance. Id. at $761 \mathrm{n} .19$.

10. There will be implications of these decisions in many other areas of accountability, including securities, foreign corruption, etc. For a discussion on such potential implications, see generally Aaron Simowitz, Legislating Transnational Jurisdiction, 57 VA. J. INT'L L. (forthcoming 2017).

11. In addition to restrictions on general personal jurisdiction, two other fairly universal doctrines contribute to preventing victims of extraterritorial human rights violations from seeking justice in the courts of the United States: limits on subject matter jurisdiction over extraterritorial conduct under the ATS in light of Kiobel v. Royal Dutch Petrol., 133 S. Ct. 1659 (2013), and the limited liability of parent corporations for acts of their subsidiaries. For discussion regarding the limitations of subject matter jurisdiction and shareholder limited liability, see Gwynne L. Skinner, Beyond Kiobel: Providing Access to Judicial Remedies for Corporate Accountability for Violations of International Human Rights Norms by Transnational Corporations in a New (Post-Kiobel) World, 46 COLUM. HUM. RTS. L. REV. 158, 169-73 (2014) (addressing, inter alia, subject matter jurisdiction) [hereinafter Skinner, Beyond Kiobel], and Gwynne L. Skinner, Rethinking Limited Liability of Parent Corporations for Foreign Subsidiaries' Violations of International Human Rights Law, 72 WASH. \& LEE L. REV. 1769 (2015) (addressing limited liability of parent corporations) [hereinafter Skinner, Rethinking Limited Liability].

12. Alien Tort Statute, 28 U.S.C. $\S 1350$ (2012). The Supreme Court held that the ATS is a jurisdictional statute, but that when Congress enacted the ATS it did so with the understanding that courts would use their common law power to recognize such claims. Sosa v. Alvarez-Machain, 542 U.S. 692, 712, 724 (2004). As discussed in more detail infra Part II.A, the Supreme Court in Kiobel limited the extraterritorial application of the ATS to those claims that "touch and concern" the United States.

13. Anti-Terrorism Act, 18 U.S.C. $\S \S 2332-33$ (2012). 
and the Trafficking Victims Protection Act (TVPA), ${ }^{14}$ and even where the TNC gains significant economic benefit by conducting business in the United States. Narrow jurisdiction will greatly impact such victims because several of the host countries where TNCs operate, and where many of the worst human rights and environmental abuses occur, have weak, ineffective, or corrupt judicial systems, and thus, victims cannot obtain a remedy in the host country where the harm occurred. ${ }^{15}$ Rather, if victims have any hope for a remedy, they often have no choice but to file a lawsuit outside of their own country. As discussed below, for many years, victims could bring such claims in U.S. courts under the Alien Tort Statute.

This Article, then, addresses the current trend in the United States ${ }^{16}$ of limiting general personal jurisdiction over TNCs that operate extraterritorially and argues that such narrow jurisdiction is inconsistent with the growth of transnational businesses, and the way in which they are structured and operate. Moreover, the narrowing will result in victims of business-related human rights abuses being left without a remedy, even as the offending TNCs gain significant economic advantage by operating in host countries where the harm occurred, as

14. Trafficking Victims Protection Act, 18 U.S.C. \& 1595 (2012). The Statute read in relevant part, "an individual who is a victim of a violation of this chapter may bring a civil action against the perpetrator (or whoever knowingly benefits, financially or by receiving anything of value from participation in a venture which that person knew or should have known has engaged in an act in violation of this chapter) in an appropriate district court of the United States and may recover damages and reasonable attorneys fees." Id.

15. See Christen Broecker, Note, "Better the Devil You Know": Home State Approaches to Transnational Corporate Accountability, 41 N.Y.U. J. INT'L L. \& POL. 159, 184-85 (2008); Brittany T. Cragg, Comment, Home is Where the Halt Is: Mandating Corporate Social Responsibility Through Home State Regulation and Social Disclosure, 24 EMORY INT'L L. REV. 735, 751-55 (2010); Erin Foley Smith, Right to Remedies and the Inconvenience of Forum Non Conveniens: Opening U.S. Courts to Victims of Corporate Human Rights Abuses, 44 ColUM. J.L. \& SoC. PROBS. 145, 156-58 (2010).

16. Although outside the scope of this Article, similar personal jurisdictional limits exist in much of Europe. See generally Council Regulation 1215/2012 (recast), 2012 O.J. (L 351) (EU) [hereinafter Brussels I recast]. Most of Europe, including the EU, does not make a distinction between personal jurisdiction and subject matter jurisdiction in the same way that the United States does and jurisdiction is not a matter of constitutional doctrine, but is purely statutory. See Linda J. Silberman, Goodyear and Nicastro: Observations from a Transnational and Comparative Perspective, 63 S.C. L. REV. 591, 612 (2012). In Europe, jurisdictional rules focus both on the domicile of the defendant and on the type of claim being brought, with different jurisdictional rules applying in different types of cases and depending on who is bringing the claim. See id.; see Brussels I recast, at pmbl. 13, 15; see also id. at art. 4. Although there are no constitutional limitations on personal jurisdiction under EU regulations, the reasons for some jurisdictional limitations are based on notions of fairness-similar to the U.S. jurisprudential focus on due process rights of defendants. Id. at pmbl. 1, 3 . 
well as in countries that severely limit personal jurisdiction over them, which now includes the United States. Given the complexities of corporate structures, and the often overwhelming barriers victims face when seeking remedies for corporate-related human rights abuses, countries where TNCs engage in business, such as the United States, should be expanding general personal jurisdiction over transnational corporate entities, not narrowing such jurisdiction.

Thus, this Article proposes that the United States broaden general personal jurisdiction over TNCs that do business in the United States so that victims of business-related human rights violations have a chance at a remedy pursuant to existing (and potentially future) causes of action, which in the human rights context often includes claims involving extraterritorial conduct. The Article suggests that the most expedient way for this to occur is for the U.S. Congress to enact a statute specifically requiring that TNCs "doing business" in the United States consent to the personal jurisdiction of U.S. courts in those instances where Congress has provided a cause of action for extraterritorial conduct, including the ATS. ${ }^{17}$ As discussed in more detail infra Part VI.A, Congress could define "doing business" in a number of ways. Congress has the power to enact such a statute under the Commerce Clause of the U.S. Constitution. ${ }^{18}$

Part I of the Article briefly describes the evolution of general personal jurisdiction over transnational corporations in the United States. It notes how U.S. courts adapted general personal jurisdiction to meet the problems posed by businesses through their expansion across state lines and internationally early in the 1900 s in order to ensure fairness and justice for victims of business-related harm. This Part also discusses the 1945 case International Shoe, which although limited courts' assertion of personal jurisdiction over corporations, still seemingly allowed such assertions of general personal jurisdiction where a corporation engaged in substantial continuous activity. Part II discusses how the "continuous and systematic" test courts derived from International Shoe for asserting general personal jurisdiction allowed victims of business-related human rights abuses to file suit against TNCs for such harms in U.S. courts after the reemergence of the Alien Tort Statute in the early 1980s. Part III

17. As mentioned, supra note 12 , Congress did not specifically enact a cause of action in the ATS, but provided for subject matter jurisdiction over torts in violation of the law of nations. However, Congress did so with the understanding that providing such jurisdiction would enable courts to use their common law powers to recognize such claims. Sosa, 542 U.S. at 712. In this way, Congress "provided for" a cause of action within the meaning of this Article.

18. U.S. ConST. art. I, $\S 8$, cl. 3 (granting Congress the power to "regulate Commerce with foreign Nations"). 
discusses Goodyear and Daimler's narrowing of general personal jurisdiction over TNCs, as well as the related narrowing of specific jurisdiction in $J$. McIntyre Machinery, Ltd. v. Nicastro. ${ }^{19}$ It also discusses the Court's narrowing of subject matter jurisdiction for extraterritorial human rights violations in Kiobel v. Royal Dutch Petroleum $^{20}$ in 2013, but notes that ATS claims are alive and well.

Part IV discusses Goodyear's and Daimler's implications, including the implication of limiting victims of extraterritorial human rights abuses from seeking and obtaining a remedy against these transnational corporations in U.S. courts. It also discusses the decisions' effect on other claims, such as claims brought for terrorism-related violations. This Part also compares the limiting of general personal jurisdiction over corporations to that of courts' ability to assert jurisdiction over individuals who are served while within the court's jurisdiction-known as "tag" jurisdiction" - noting the unfairness of this scheme.

Part V of the Article discusses why such narrow general personal jurisdiction over transnational businesses is unjust and why Congress should address the problem. This Part discusses the enormous financial and tax benefits corporations receive from operating in developing "host countries," yet all the while, nonconsenting victims are forced to absorb nearly all the costs of harm. Moreover, such victims are typically unable to seek a remedy in the courts of their own countries, for a variety of reasons. They are also often unable to seek remedy in Europe against corporations domiciled there for a variety of reasons, including lack of causes of action and the existence of loser pay rules, which makes being able to bring claims in the United States even more important. This Part also describes that today transnational businesses are so complex in their structure and operations that narrow personal jurisdiction no longer is fair or justifiable. Finally, this Part also notes the enormous amount of business and direct investment of foreign transnational companies in the United States as a reason why expanding general personal jurisdiction over such transnational businesses in the United States is fair.

Part VI proposes the specific solution: that Congress enact a law allowing U.S. courts to assert general personal jurisdiction over all TNCs and other entities "doing business" in the United States where Congress has seen fit to provide a cause of action for extraterritorial conduct. Although it may be possible for states to do this as well, given the

19. J. McIntyre Mach., Ltd. v. Nicastro, 564 U.S. 873 (2011).

20. Kiobel v. Royal Dutch Petrol. Co., 133 S. Ct. 1659 (2013).

21. See infra note 220 .

22. Other entities would include Non-Government Organizations (NGOs), some of which have been alleged to be involved in funding terrorism. See discussion infra Part IV.A, involving the NGO Tamil Rehabilitation Organization (TRO), as an example. 
possible limitations of the Commerce Clause, ${ }^{23}$ federalism, and the foreign affairs doctrine, it is more expedient and feasible for Congress to enact such legislation, which it is empowered to do under the Commerce Clause. Such legislation would provide non-domestic corporations fair notice of general jurisdiction for these claims, primarily human rights, terrorism, and trafficking claims, among potentially others. Moreover, "doing business" would include the existence of a subsidiary in the United States through which the parent engages in the business of the enterprise. Although not a focus of this Article, this Part also suggests that Europe and Canada take similar action with regard to TNCs operating within their jurisdiction where a cause of action for extraterritorial conduct exists. ${ }^{24}$

Part VI also argues that expanding personal jurisdiction over foreign corporations doing business in the jurisdiction would create an even playing field for the United States businesses because most transnational businesses, wherever such are incorporated, would be equally subject to suits under federal law, not just U.S. companies. This Part concludes by addressing comity and foreign relations concerns, noting that while such concerns are legitimate, they are likely overstated.

\section{EVOlution of U.S. COURTS' General Personal JuRisdiction OVER TRANSNATIONAL CORPORATIONS.}

Much has been written about the history of personal jurisdiction, as well as the changing justifications for constitutional limitations on personal jurisdiction (i.e., state sovereignty vs. constitutional due

23. See discussion infra Part V; see also Charles W. "Rocky" Rhodes \& Cassandra Burke Robertson, Toward a New Equilibrium in Personal Jurisdiction, 48 U.C. DAVIS L. REV. 207, 261-62 (2014) (noting that some courts question whether states can require such consent from foreign corporations under the Dormant Commerce Clause) [hereinafter Rhodes \& Robertson, Toward a New Equilibrium in Personal Jurisdiction]; Wendy Collins Perdue, Personal Jurisdiction and the Beetle in the Box, 32 B.C.L. REv. $529,550-51$ (1991) (noting concerns of state's inability to require consent under the Commerce Clause) [hereinafter Perdue, Personal Jurisdiction and the Beetle in the Box].

24. See Brussels I recast, supra note 16 , at pmbl. 14; id. at ch. II, $\S 1$, art. 6 . For corporations not domiciled in an EU country, each country in Europe has its own jurisdictional laws that govern such entities, and personal jurisdiction over such non-EU corporations ranges and can be quite broad. Id.

In Canada, jurisdiction is broader than it now exists in the United States postDaimler. See Club Resorts, Ltd. v. Van Breda, [2012] 1 S.C.R. 572 (Can.) (explaining that jurisdiction over out-of-province or out-of-country defendants is based on whether the foreign corporation has a "real and substantial connection" to Canada (and the province asserting jurisdiction)); see also Caroline Davidson, Tort Au Canadien: A Proposal For Canadian Tort Legislation on Gross Violations of International Human Rights and Humanitarian Law, 38 VAND. J. TRANSNAT'L L. 1403, 1437-38 (2005). 
process), and that history will not be repeated in detail here. ${ }^{25}$ However, a summary of the history of the evolution of personal jurisdiction over

25. See, e.g., Neirbo Co. v. Bethlehem Shipbuilding Corp., 308 U.S. 165, 169 (1939) (describing the "long, tortuous evolution" of personal jurisdiction precedent with respect to corporations as a "history of judicial groping for a reconciliation between the practical position achieved by the corporation in society and a natural desire to confine the[ir] powers"). Although impossible to list all the writings regarding the history and changing justifications, some of the more frequently cited and influential articles include Patrick J. Borchers, The Death of the Constitutional Law of Personal Jurisdiction: From Pennoyer to Bumham and Back Again, 24 U.C. DAVIS L. REv. 19, 23-25 (1990) (arguing that Pennoyer was not intended to make personal jurisdiction a constitutional law issue, but rather that personal jurisdiction is better regulated through legislators and Congress); Lea Brilmayer et al., A General Look at General Jurisdiction, 66 Tex. L. Rev. 721, 782-83 (1988) (arguing that direct affiliations, such as domicile or principle place of business, are sufficient contacts to subject a defendant to both adjudicative and legislative general jurisdiction); Robert C. Casad, Personal Jurisdiction in Federal Question Cases, 70 TeX. L. REV. 1589, 1592 (1992) (arguing that the International Shoe requirement for establishing personal jurisdiction in federal question cases should be satisfied by proving a basis of contacts within the U.S. as a whole, rather than focusing on contacts within a specific state); Terry S. Kogan, A Neo-Federalist Tale of Personal Jurisdiction, $63 \mathrm{~S}$. CAL. L. REv. 257, 265-67 (1990) (arguing that the evolution of personal jurisdiction is linked to major political and social events in U.S. history, and that after each event, personal jurisdiction has helped the People understand the roles of the federal government and the states by testing their limits); Harold S. Lewis, Jr., The Three Deaths of State Sovereignty and the Curse of Abstraction in the Jurisprudence of Personal Jurisdiction, 58 NOTRE DAME L. REv. 699, 726-27 (1983) (arguing that the purpose of personal jurisdiction is to protect an individual's constitutional rights, rather than protecting a state's interest, which means personal jurisdiction can be waived, consented or estopped); Wendy Collins Perdue, What's "Sovereignty" Got to Do with It? Due Process, Personal Jurisdiction, and the Supreme Court, 63 S.C. L. REv. 729, 740-43 (2012) (describing that personal jurisdiction has changed from evaluating a state's sovereign power to adjudicate a case to ensuring that the defendant's liberty interest is not violated; and arguing that a new approach to personal jurisdiction must be adopted as sovereignty and federalism no longer function); Perdue, Personal Jurisdiction and the Beetle in the Box, supra note 23, at 529-34 (describing the history of personal jurisdiction in the United States, and noting that every few years, the Court's description of personal jurisdiction is inconsistent with its recent prior precedent); Wendy Collins Perdue, Sin, Scandal, and Substantive Due Process: Personal Jurisdiction and Pennoyer Reconsidered, 62 WASH. L. REV. 479, 503-08, 519-20(1987) (providing an in-depth analysis of Pennoyer v. Neff and substantive due process); Charles W. "Rocky" Rhodes, Clarifying General Jurisdiction, 34 SETON HALL L. REV. 807, 887-902, 919-20 (2004) (describing general jurisdiction's framework; and arguing that current approaches to general jurisdiction are deficient); Allan R. Stein, Styles of Argument and Interstate Federalism in the Law of Personal Jurisdiction, 65 TEX. L. REV. 689, 738-60 (1987) (describing that theories of personal jurisdiction and the due process clause are not linked, and arguing that a state's sovereign immunity and a defendant's liberty interest need to be connected when determining 'fairness' for asserting jurisdiction); Mary Twitchell, The Myth of General Jurisdiction, 101 HARV. L. REV. 610, 629-36, 680-81 (1988) (describing that the concepts of general jurisdiction and specific jurisdiction have strayed from their original meaning, and arguing that the broadest meaning of specific jurisdiction should be adopted and that general jurisdiction should be restricted to cases that are truly dispute-blind); and von Mehren \& Trautman, supra note 3, at 1164-79 (describing why general and specific jurisdictions are better terms than in personam, in 
corporations is important in understanding how we arrived at where we are today, with limited general personal jurisdiction over transnational corporations after Goodyear and Daimler.

\section{A. Early U.S. History of General Jurisdiction Over Corporations}

Early in our country's history, whether a court could exercise personal jurisdiction over a defendant was based simply on whether the court was able to physically enforce a judgment against the defendanti.e., power over the defendant or his property. ${ }^{26}$ Thus, courts could assert jurisdiction over a defendant where the defendant was "found" and served. ${ }^{27}$ Courts could assert jurisdiction over an individual not domiciled in the state, as long as he was found in the state and served there. ${ }^{28}$

However, courts could assert jurisdiction over corporations only in their state of incorporation because a corporation was not seen as having a legal existence outside the boundaries of the state where it was created. ${ }^{29}$ A corporation could not "migrate" to another sovereign state for purposes of jurisdiction or otherwise. ${ }^{30}$ Similarly, service on an individual officer outside of the state of incorporation was typically not valid because corporate officers were thought to lose their official character representing the corporation as soon as they left the state of

rem, and quasi in rem, and arguing that in the future, specific jurisdiction will be the prominent approach while general jurisdiction will be limited and eventually disappear).

26. W.F. BAILEY, THE LAW OF JURISDICTION, INCLUDING IMPEACHMENT OF JUDGMENTS, LIABILITY FOR JUDICIAL ACTS, AND SPECIAL REMEDIES (1st ed. 1899); McDonald v. Mabee, 243 U.S. 90, 91-92 (1917) (reasoning by Justice Holmes where he famously noted that "[t]he foundation of jurisdiction is physical power ... the ground for giving subsequent effect to a judgment is that the court rendering it had acquired power to carry it out ....."); Int'l Shoe Co. v. Washington, 326 U.S. 310, 316 (1945) ("[h]istorically the jurisdiction of courts to render judgment in personam is grounded on their de facto power of the defendant's person").

27. See, e.g., Louisville, Cincinnati, \& Charleston R.R. Co. v. Letson, 43 U.S. 497 (1844); Bank of Augusta v. Earle, 38 U.S. 519 (1839). See also 4 CharLes ALAN Wright \& Arthur R. Miller, Federal Practice and Procedure $\S 1066$ (4th ed. 2016).

28. See Wright \& MiLlER, supra note 27. The Supreme Court confirmed this in Pennoyer $v$. Neff, 95 U.S. 714, 734 (1878), where it held that consistent with due process, a court could only assert jurisdiction over a non-consenting defendant who was either physically residing or domiciled within the state or a non-citizen served while in the state.

29. See WRIGHT \& MILLER, supra note 27 ("[A] corporation can have no legal existence out of the boundaries of the sovereignty by which it is created. It exists only in contemplation of law, and by force of the law; and where that law ceases to operate, and is no longer obligatory, the corporation can have no existence. It must dwell in the place of its creation, and cannot migrate to another sovereignty."); RICHARD D. FREER \& Wendy Collins Perdue, Civil Procedure: Cases, Materials, and Questions 32 (5th ed. 2008).

30. Id. (internal citations omitted). 
incorporation. ${ }^{31}$ Thus, until about the middle of the 1800 s, unless the corporation owned property in the state and attachment was available, ${ }^{32}$ victims were out of luck if they wanted to bring a case in the state where they lived and where the injury occurred. Although a corporation was permitted to institute an action outside its state of incorporation, a plaintiff could only sue a corporation in the state where it was incorporated. $^{33}$

During the 18th and most of the 19th centuries, this lack of a court's ability to assert personal jurisdiction over a foreign corporation was not a looming issue because corporations typically operated only within the boundaries of the state that created them. ${ }^{34}$ As corporations began doing business across state lines, especially after the industrial revolution, courts struggled with how to properly assert personal jurisdiction over corporations incorporated in other states. ${ }^{35}$ Limiting suits against them to only one state-where they were incorporated-seemed both unrealistic and unfair, resulting in a need to revise jurisdictional rules to match the way corporations were increasingly operating. ${ }^{36}$

Courts initially flirted with the idea of asserting personal jurisdiction based on a corporation's consent either when a state explicitly required consent or where it was implied. ${ }^{37}$ This appears to have been the case, especially where the cause of action arose from business transactions within the state ${ }^{38}$-a precursor to specific personal

31. WRIGHT \& Miller, supra note 27 (citing McQueen v. Middletown Mfg. Co., 16 Johns. R. 5, 7 (N.Y. Sup. Ct. 1819)).

32. Id.

33. $I d$.

34. Id.

35. See id.

36. See id. (citing Charles E. Clark, Chief Judge of the Second Circuit, in Deveny v. Rheem Mfg. Co., 319 F.2d 124, 126 (2d Cir. 1963) ("In the late nineteenth century, and continuing on into our own, increased use of the corporate form, together with the greater mobility afforded by modern means of transportation, brought about an expansion of corporate activity to a nationwide scale; corporations simply refused to remain penned up within their own states of incorporation. The existence of corporations which couldand did-do business on a nationwide scale necessitated revision of older, more limited, notions concerning jurisdiction.")).

37. Id.; see also Lafayette Ins. Co. v. French, 59 U.S. 404, 407 (1855) (noting that a corporation could only transact business in another state upon consent, and that consent could be accompanied by such conditions as the state saw fit to impose. The court further noted that "[i]t cannot be deemed unreasonable that the State of Ohio should endeavor to secure to its citizens a remedy, in their domestic forum, upon this important class of contracts made and to be performed within that State, and fully subject to its laws; nor that proper means should be used to compel foreign corporations, transacting this business of insurance within the State, for their benefit and profit, to answer there for the breach of their contracts of insurance there made and to be performed."); St. Clair v. Cox, 106 U.S. 350 (1882).

38. See St. Clair, 106 U.S. at 356. In St. Clair, Justice Field noted: 
jurisdiction. Justice Field also alluded to the theory in the famous 1878 case of Pennoyer v. Neff, ${ }^{39}$ where he noted that one option to overcome jurisdictional barriers was simply to require a corporation to appoint an agent for service of process as a condition for doing business within the state as a type of "consent." 40

Nonetheless, courts differed on whether the consent theory was fair to corporations and whether consent was genuine, especially where the cause of action did not arise from the corporations' actions with the state asserting jurisdiction. ${ }^{41}$ Thus, in the 1800 s and early 1900 s, it never was universally adopted as a theory of general personal jurisdiction. ${ }^{42}$

The consent theory continued to remain a questionable theory of jurisdiction. Requiring "consent," of course, was based on the assumption that states could prevent a foreign corporation from operating within its territory. Indeed, by the time of Pennoyer, the Supreme Court had already held that although states could not exclude natural persons domiciled in other states from their territory under the Privilege and Immunities Clause, ${ }^{43}$ the Clause did not protect corporations from such exclusion. ${ }^{44}$ However, in 1910 , the Supreme Court recognized that while the Privilege and Immunities Clause might not prevent a state from excluding a foreign corporation from operating within it-in that case, for failure to file a financial statement-or prevent a corporation from filing suit in the state, the Commerce Clause did. $^{45}$ Yet, despite this

The State may, therefore, impose as a condition upon which a foreign corporation shall be permitted to do business within her limits, that it shall stipulate that in any litigation arising out of its transactions in the State, it will accept as sufficient the service of process on its agents or persons specially designated; and the condition would be eminently fit and just. And such condition and stipulation may be implied as well as expressed.

Id. (emphasis added). See also Lafayette, 59 U.S. at 407.

39. Pennoyer v. Neff, 95 U.S. 714 (1878). This case is best known for its general holding that a state court cannot exercise personal jurisdiction over a nonresident who has not been personally served while within the state and whose property within the state was not attached before the onset of litigation. See id. at 735-36.

40. Id. at 735 .

41. Id.; see also WRIGHT \& MILLER, supra note 27, at § 1066.

42. See discussion infra at Part $\mathrm{V}$ regarding more recent cases involving consent.

43. U.S. ConST. art. IV, $\$ 2$, cl. 1.

44. See Paul v. Virginia, 75 U.S. 168, 177 (1869) (holding that corporations were not protected by the Privileges and Immunities Clause).

45. See Int'l Textbook Co. v. Pigg, 217 U.S. 91, 108-09 (1910) (finding that a state could not preclude a foreign corporation from operating within it if it failed to provide a financial statement, nor prevent it from bringing a case in state court if it failed to register; such was only within the powers of Congress) (citing Crutcher v. Commonwealth of Kentucky, 141 U.S. 47, 56-57 (1891) (finding that a state could not require a foreign company to pay a license fee and file a financial statement as a means of engaging in interstate commerce, as such was a violation of the Commerce Clause)). For some reason, few of the more recent cases discussing consent to jurisdiction mention this case. 
ruling, some courts continued to allow states to assert jurisdiction via consent through the appointment of an agent for service in the state where it did business, especially (but not always) where the cause of action arose from the contacts. ${ }^{46}$ As discussed in more detail in Part VI, the Supreme Court has never decided the question directly. It is also questionable whether the state-based consent theory survived International Shoe, where the Court focused on the number of contacts a business had with a state, ${ }^{47}$ and whether it survived Daimler and Goodyear, discussed infra Part VI.

In any event, perhaps due to other criticisms of the "consent" theory, such that consent through appointment and service was not genuine consent, courts, including the Supreme Court, soon returned (if they had departed at all) to the notion of "presence" to assert general personal jurisdiction over corporations. ${ }^{48}$ : The Supreme Court determined "presence" by the level of economic activity a business engaged in, and began using the term "doing business." 49 The Supreme

46. WRIGHT \& MILLER, supra note 27, at § 1066; see also Philip Kurland, The Supreme Court, the Due Process Clause and the In Personam Jurisdiction of State Courts-From Pennoyer to Denckla: A Review, 25 U. CHI. L. REV. 569 (1958).

47. See Cognitronics Imaging Sys. v. Recognition Research Inc., 83 F. Supp. 2 d 689 (E.D. Va. 2000). In Cognitronics, the court stated:

Although the Supreme Court affirmed the [Pennsylvania Fire] principle in 1939, the Court's decision in [International Shoe], cast doubt on the continued viability of these cases. After International Shoe, the focus shifted from whether the defendant had been served within the state to whether the defendant's contacts with the state justified the state's assertion of jurisdiction.

Id. at 692. See also Lea Brilmayer \& Kathleen Paisley, Personal Jurisdiction and Substantive Legal Relations: Corporations, Conspiracies, and Agency, 74 CALIF. L. REV. $1,36-37$ (1986).

48. WRIGHT \& MILLER, supra note 27, at § 1066; Int'l Harvester v. Kentucky, 234 U.S. 579,588 (1914) ("We are satisfied that the presence of a corporation within a state necessary to the service of process is shown when it appears that the corporation is there carrying on business in such sense as to manifest its presence within the state."); People's Tobacco Co. v. Am. Tobacco Co., 246 U.S. 79, 84 (1918) (equating "found" as being "present"); Green v. Chicago, B. \& Q. Ry., 205 U.S. 530, 532 (1907) (finding that jurisdiction "depends upon whether the corporation was doing business in that district in such a manner and to such an extent as to warrant the inference that, through its agents, it was present there"); St. Louis S.W. Ry. Co. v. Alexander, 227 U.S. 218, 227 (1913) ("[T]he business must be such in character and extent as to warrant the inference that the corporation has subjected itself to the jurisdiction and laws of the district in which it is served, and in which it is bound to appear when a proper agent has been served with process.").

49. See Int'l Harvester, 234 U.S. at 582-86 (using the term "doing business" throughout to determine level of presence); see also People's Tobacco Co., 246 U.S. at 84 (noting that presence is determined by the level of business a defendant's agents engaged in); Green, 205 U.S. at 532-34 (using the term "doing business" throughout to determine level of presence); FREER \& PERDUE, supra note 29, at 33. 
Court refrained from articulating a specific test as to how much business was enough for general personal jurisdiction and said courts should determine general personal jurisdiction on a case-by-case basis. ${ }^{50}$ The Court itself did just that in the early 1900s. ${ }^{51}$

As time progressed, lower courts began to focus specifically on what constituted "doing business," 52 but increasingly failed to equate the level of "doing business" with the notion of "presence." 53 Courts would find there was general personal jurisdiction whenever a business was "doing business" within the jurisdiction, even when the level of business was fairly minimal. ${ }^{54}$ This more expansive notion of "doing business," which was not equated with "presence" itself, proved difficult for courts to apply, and was particularly problematic for the Supreme Court.

\section{$B$. International Shoe}

In the 1945 case of International Shoe Co. v. Washington, ${ }^{55}$ the Supreme Court reigned in the expansive, "doing business"-based general jurisdiction over foreign corporations. In so doing, the Court set forth the test lower courts would rely on in determining personal jurisdiction for the next 65-plus years: that assertions of personal jurisdiction over a nonresident corporate defendant satisfy due process ${ }^{56}$ where the business has "certain minimum contacts with [the forum] such that the maintenance of the suit does not offend 'traditional notions of fair play and substantial justice." 57

The issue in International Shoe was whether the State of Washington could assert personal jurisdiction over the Delaware corporation, which had its principal place of business in Missouri, for

50. See Int'l Harvester, 234 U.S. at 583; see also People's Tobacco Co., 246 U.S. at $86-87$.

51. See, e.g., Int'l Harvester, 234 U.S. at 583-84 (holding the company engaged in continuous solicitation of orders through local agents in Kentucky, shipped equipment to these agents, and the agents continuously accepted payments for the equipment, thus doing sufficient business to provide for general jurisdiction); see also People's Tobacco Co., 246 U.S. at 84-85, and Green, 205 U.S. at 533 (holding in both that based on a caseby case analysis, the level of a foreign corporation's business activity was not enough to for a court to assert personal jurisdiction).

52. See Kurland, supra note 46, at 584-86; see also FREER \& PERDUE, supra note 29 , at 36 .

53. Kurland, supra note 46 , at $584-85$.

54. Id.

55. Int'l Shoe Co. v. Washington, 326 U.S. 310 (1945).

56. Id. at 320 . As early as 1886 , the U.S. Supreme Court held that the Fourteenth Amendment applied to corporations. See Santa Clara Cty. v. S. Pac. R.R., 118 U.S. 394, 396 (1886).

57. Int'l Shoe, 326 U.S. at 316 (citing Milliken v. Meyer, 311 U.S. 457, 463 (1940) (holding that individuals can be sued in the state of their domicile for all claims, as such satisfies due process, i.e., "traditional notions of fair play and substantial justice")). 
failing to pay into the state unemployment compensation fund given that it had several salesmen living and operating in Washington State. ${ }^{58}$ The Supreme Court held that the lower court could assert jurisdiction over the business, given that its salesmen operated "systematically and continuously" in the state by soliciting orders, and that a large volume of merchandise was regularly shipped into the state as a result of those orders. ${ }^{59}$ The Court did not directly hold that the claims sued upon had to arise out of the contacts for there to be personal jurisdiction. The Court did note, however, perhaps as an aside, that the obligation "which is here sued upon arose out of those very activities,"60 - what we now refer to as specific jurisdiction. It is this comment that led Justice Ginsberg to determine in Goodyear and Daimler that the "systematic and continuous" language relates to specific jurisdiction, not general personal jurisdiction. ${ }^{6}$

Although the Court did not directly specify the level of contacts sufficient for specific jurisdiction versus general jurisdiction other than to indicate that the contacts must be more substantial for assertions of general personal jurisdiction than for specific jurisdiction, it did state that "there have been instances in which the continuous and corporate operations within a state were thought so substantial and of such a nature as to justify suit against it on causes of action arising from dealings entirely distinct from those activities. ${ }^{, 62}$ Thus, the Court recognized that contacts may be sufficiently continuous and substantial to assert general personal jurisdiction over a foreign corporation.

\section{General Personal Jurisdiction Over Transnational Corporations Post-International Shoe}

After International Shoe, U.S. courts often relied on the case to assert general personal jurisdiction over foreign corporations, finding that the corporations had engaged in sufficiently systematic and continuous business to justify courts' assertions of general personal jurisdiction. ${ }^{63}$ They did so with little controversy or intervention by

58. Id. at 311-13.

59. Id. at 319-20.

60. Id. at 320; see also id. at 314.

61. See infra at Section III.A.

62. Int'l Shoe, 326 U.S. at 318 (emphasis added) (citing Missouri, K. \& T.R. Co. v. Reynolds, 255 U.S. 565 (1921); Tauza v. Susquehanna Coal Co., 115 N.E. 915 (N.Y. 1917); St. Louis S.W. Ry. Co. v. Alexander, 227 U.S. 218 (1913)).

63. See, e.g., Burnett v. Al Baraka Inv. \& Dev. Corp., 274 F. Supp. 2d 86, 96 (D.D.C. 2003) (holding that two of the defendant corporations were subject to general personal jurisdiction given the level of contacts within the United States as a whole, for purposes of allowing jurisdictional discovery against bank); Gorman v. Ameritrade Holding Corp., 293 F.3d 506, 512 (D.C. Cir. 2002) (finding that a broker conducting 
Congress. The Supreme Court only addressed general personal jurisdiction over a foreign corporation twice between International Shoe and Goodyear, each time applying the test it set forth in International Shoe. Regarding the facts of each case relevant for the general personal jurisdiction test, they were on quite different ends of the scale.

The first case was the 1952 case of Perkins v. Benguet Consolidated Mining $\mathrm{Co}^{64}$ In that case, which involved the rights of a stockholder, the U.S. Supreme Court held that the lower court could assert general personal jurisdiction over a Philippines-based mining company in Ohio, where the corporate defendant had temporarily located its headquarters during the Japanese occupation of the Philippines in the wake of World War II, thus engaging in continuous and systematic business there. ${ }^{65}$ The second case was the 1984 case of Helicopteros Nacionales de Columbia, S.A. v. Hall, ${ }^{66}$ a case involving a helicopter crash in Peru, with the owners of the helicopter, Helicopteros; a Columbian corporation being sued in Texas. Although the Court affirmed that general personal jurisdiction could exist where there is "continuous and systematic" business activity, ${ }^{67}$ it rejected the argument that general personal jurisdiction could be asserted in Texas based on the facts of the case. The Court declined to assert personal jurisdiction over Helicopteros, noting that the corporation did not have a place of business in Texas, and that the contacts were based upon (1) a one-time visit by the CEO to

business entirely online, targeting DC residents and local businesses and receiving revenue from those transactions, met the continuous and systematic contacts required for general personal jurisdiction, but dismissing the case due to improper service of process); Bankhead Enter., Inc. v. Norfolk \& W. Ry., 642 F.2d 802, 805-06 (5th Cir. 1981) (finding general personal jurisdiction where defendant leased an office and employed sales agents and clerical staff); Hayes v. Evergo Tel. Co., 397 S.E.2d 325, 329 (N.C. App. 1990) (finding general personal jurisdiction over a Hong Kong Corporation proper where it sold $\$ 35$ million of products throughout United States); Sternberg v. O'Neil, 550 A.2d 1105, 1127 (Del. 1988) (holding that consistent with International Shoe, asserting general personal jurisdiction over a foreign corporation operating a wholly-owned subsidiary in Delaware for thirty years was proper); Braband v. Beech Aircraft Corp. 382 N.E.2d 252, 257 (Ill. 1978) (finding general personal jurisdiction based on systematic and continuous contacts where defendant sold products in Illinois through independent dealer and sponsored sales promotions in Illinois, and required dealer to perform warrant work on all of manufacturer's products and to make records and facilities available for inspection); Bryant v. Finnish Nat'l Airline, 208 N.E.2d 439, 441 (N.Y. 1965) (finding general personal jurisdiction over foreign airline which maintained a one-and-a-half room office and employed several people in the state). Many courts continued to use the term "systematic and continuous business," even though International Shoe used the term "so substantial and of such a nature to justify" general personal jurisdiction. Int'l Shoe, 326 U.S. at 318 .

64. Perkins v. Benguet Consol. Mining Co., 342 U.S. 437 (1952).

65. Id. at 438,449 .

66. Helicopteros Nacionales de Columbia, S.A. v. Hall, 466 U.S. 408 (1984).

67. Id. at 416 . 
Texas for a negotiation session, (2) that it had accepted checks drawn upon a Texas bank,(3) that it had purchased helicopters, equipment, and training services from a Texas-based company, and (4) that it had sent personnel to Texas for training on the equipment. ${ }^{68}$ For the Court, these facts were simply not enough to permit the assertion of general personal jurisdiction. ${ }^{69}$

The Court's analysis in Helicopteros gives some guidance as to how much business activity the Court believed was sufficient for lower courts to assert general personal jurisdiction before Goodyear and Daimler. A one-time visit to the state, banking, and purchases and training were not sufficiently continuous and systematic to equate to "presence" under International Shoe. In distinguishing Perkins from Helicopteros, the Court noted that in Perkins, the corporation had carried on a "continuous and systematic," albeit limited, part of its general business" in Ohio when the president and general manager temporarily maintained an office there and conducted activities on behalf of the corporation, such as holding directors' meetings, sending out correspondence, keeping the company files, distributing salary checks drawn on two Ohio banks, and supervising policies related to the corporation's properties in the Philippines. ${ }^{71}$ Perkins is an easy case, so easy that sixty-one years later, in Daimler, the Court noted that the circumstances in Perkins were the type that might allow a court to assert general personal jurisdiction over corporations in "exceptional circumstances." ") Given the rarity of the Supreme Court speaking on the issue of general personal jurisdiction after International Shoe and before Goodyear, and the very divergent facts in Perkins and Helicopteros, it remains unclear whether the Supreme Court would have always required such overwhelming facts of presence to assert general business jurisdiction, or if lesser facts (but better than in Helicopteros) would have been sufficient. We will never know. What we do know, however, is that International Shoe and its progeny allowed courts to assert general personal jurisdiction over TNCs engaged in sufficiently systematic and continuous business in the United States and which were accused of violating customary international human rights laws when victims sought relief in U.S. courts, particularly under the ATS.

68. Id. at 416,426 .

69. Id. at 418 .

70. Id. at 421 (citing Perkins, 342 U.S. at 438).

71. Id. at 415 (citing Perkins, 342 U.S. at 438,445 ).

72. See Daimler AG v. Bauman, 134.S. Ct. 746, 761 n.19 (2014). 
II. MODERN DEVELOPMENT OF HUMAN RightS CLAIMS IN THE UNITED STATES UNDER THE ALIEN TORT STATUTE, AND COURTS' ASSERTION OF GENERAL PERSONAL JURISDICTION OVER TRANSNATIONAL CORPORATIONS INVOLVED IN SUCH CLAIMS

\section{A. The Modern Development of the ATS}

In 1789, Congress enacted the Alien Tort Statute ${ }^{73}$, which allows noncitizens to bring claims in federal court for violations of "the law of nations," which courts commonly equate with customary international law. ${ }^{74}$ The statute was virtually ignored for nearly two centuries, ${ }^{75}$ until the 1980 case of Filartiga v. Pena-Irala ${ }^{76}$ involving torture claims against a former Paraguayan military officer, gave it new life. Although the defendant in Filartiga lived in New York at the time, the statute does not limit who can be defendants, ${ }^{77}$ and does not exclude claims arising from extraterritorial conduct. ${ }^{78}$ Importantly, the Second Circuit rejected the argument that U.S. courts could not assert subject matter jurisdiction to hear the case ${ }^{79}$ because it involved extraterritorial conduct by a foreign

73. 28 U.S.C. $§ 1350$ (2012). Passed as part of the Judiciary Act of 1789 , the ATS reads, "The district courts shall have original jurisdiction of any civil action by an alien for a tort only, committed in violation of the law of nations or a treaty of the United States." Judiciary Act of 1789, ch. 20, § 9, 1 Stat. 73, 77 (1789).

74. The "law of nations" is generally equated with customary international law. See, e.g., The Estrella, 17 U.S. 298, 307-08 (1819) (referring to non-treaty-based law of nations as the "the customary ... law of nations"); Flores v. S. Peru Copper Corp., 414 F.3d 233, 237 n.2 (2d Cir. 2003) ("In the context of the ATCA [ATS], we have consistently used the term 'customary international law' as a synonym for the term the "law of nations."').

75. Many scholars have traced the history of the ATS. See, e.g., William R. Casto, The New Federal Common Law of Tort Remedies for Violations of International Law, 37 RUTGERS L.J. 635, 664-68 (2006); William Dodge, Bridging Erie: Customary International Law in the U.S. Legal System after Sosa, 12 TULSA J. COMP. \& INT'L L. 87, 92-95 (2004); Ryan Goodman \& Derek P. Jinks, Filartiga's Firm Footing: International Human Rights and Federal Common Law, 66 FordHAM L. REv. 463, 464-70 (1997); Kenneth C. Randall, Federal Jurisdiction over International Law Claims: Inquiries into the Alien Tort Statute, 18 N.Y.U. J. INT'L L. \& PoL. 1, 11-31 (1985); Beth Stephens, The Law of Our Land: Customary International Law as Federal Law After Erie, 66 FORDHAM L. REV. 393, 402-13 (1997).

76. Filartiga v. Pena-Irala, 630 F.2d 876 (2d Cir. 1980).

77. However, in order to hear a claim, a court must still have personal jurisdiction over any defendant. See Burnham v. Super. Ct. of Cal., 495 U.S. 604, 608-10 (1990).

78. The U.S. Supreme Court, however, limited the extraterritorial scope of the ATS in the 2013 Kiobel decision. Kiobel v. Royal Dutch Petrol. Co. 133 S. Ct. 1659, 1668-69 (2013). But Congress has never limited the ATS to conduct within the United States. See id. at 1677 (Breyer, J., concurring) (noting that "Congress, while aware of the award of civil damages under the ATS-including cases such as Filartiga with foreign plaintiffs, defendants, and conduct-has not sought to limit the statute's jurisdictional or substantive reach.")

79. Filartiga, 630 F.2d at 885 . 
official, noting that the alleged violation - torture - was of interest to all of mankind, especially given developments in human rights after World War II, squarely fitting within the ATS enacted by the First Congress. ${ }^{80}$

Although initially after Filartiga ATS claims were brought primarily against individuals, ${ }^{81}$ soon plaintiffs began bringing ATS cases against corporations-domestic and foreign-most typically for aiding and abetting human rights violations abroad. ${ }^{82}$ Between 1980 and Goodyear in 2011, approximately 312 ATS cases were brought against businesses or organizations. ${ }^{83}$ Although the ATS has been criticized, ${ }^{84}$ the statute has been an important source of relief for non-citizens seeking remedies for harms caused by TNCs' violations of international human rights law norms. ${ }^{85}$

In the 2004 case Sosa v. Alvarez-Machain, ${ }^{86}$ the U.S. Supreme Court confirmed that federal courts had subject matter jurisdiction to adjudicate claims for violations of customary international law under the ATS, and it did not limit the claims to violations occurring in the United States. ${ }^{87}$ Specifically, the Court found that the ATS was a jurisdictional statute, but that federal courts can use their common law powers to recognize claims for violations of international law norms, as long as the norms are as specifically defined and universally recognized as those violations Congress would have had in mind when it enacted the statute-piracy, attacks on diplomats, and attacks on safe passage. ${ }^{88}$ The

80. Id. at 890 .

81. Most individual defendants have been former officials of foreign governments that engaged in human rights abuses. See Richard M. Buxbaum \& David D. Caron, The Alien Tort Statute: An Overview of the Current Issues, 28 BERKELEY J. INT'L L. 511, 513 n.5 (2010).

82. Id.; see also John B. Bellinger, III, Legal Advisor, U.S. Dept. of State, Lecture at Vanderbilt Law School, Enforcing Human Rights in U.S. Courts and Abroad: The Alien Tort Statute and Other Approaches (April 11,2008); Skinner, Beyond Kiobel, supra note 11 , at 160 .

83. The calculation of the number of cases comes from reviewing the dataset attached to Cortelyou C. Kenney's article, Measuring Transnational Human Rights, 84 FORDHAM L. REV. 1053 (2015). The table of cases she compiled and relies upon can be found at http://fordhamlawreview.org/assets/Documents/Kenney_December_Dataset.xlsx (last visited June 16, 2016) [hereinafter Kenney Dataset]. This number of 312 cases is not to be confused with the $\mathbf{3 2 5}$ non-frivolous cases she explains were resolved between 1980 and 2015 that she references in her article, 84 FORDHAM L. REV. at 1067.

84. See, e.g., Eric Posner, The United States Can't Be the World's Courthouse, SLATE (Apr, 24, 2013), http://www.slate.com/articles/news_and_politics/view_from_ chicago/2013/04/the_supreme_court_and_the_alien_tort_statute_ending_human_rights_s uits.html.

85. Skinner, Beyond Kiobel, supra note 11 , at $161 \mathrm{n} .12$.

86. Sosa v. Alvarez-Machain, 542 U.S. 692 (2004).

87. Id. at $693-95$.

88. Id. at 724-25. The Court cautioned lower federal courts, however, to evaluate the claims brought in each case with a prudential eye toward whether the recognition of such a claim in a particular case might cause foreign policy complications. Id. at 727-28. 
Court also cited positively several ATS cases where the harm giving rise to the claim took place abroad, including Filartiga. ${ }^{89}$

In the April 2013 case of Kiobel v. Royal Dutch Petroleum, the U.S. Supreme Court limited the extraterritorial application of the ATS, but certainly did not preclude such claims. In Kiobel, the Supreme Court found that the presumption against extraterritoriality ${ }^{90}$ applies to ATS claims brought for violations of customary international law that occur abroad. $^{91}$ The Court held that plaintiffs can overcome the presumption by showing that a claim "touch[es] and concern[s]" the territory of the United States with sufficient force; however, a business' presence in the United States is not alone sufficient to overcome the presumption. ${ }^{92}$ In Kiobel, a plurality opinion, four of the Justices suggested in their concurring opinion that serious violations of human rights, could "touch and concern" the United States with sufficient force to overcome the presumption against extraterritoriality. ${ }^{93}$ These Justices would find the presumption against extraterritoriality overcome under the ATS if "(1) the alleged tort occurs on American soil, (2) the defendant is an American national, or (3) the defendant's conduct substantially and adversely affects an important American national interest, and that includes a distinct interest in preventing the United States from becoming a safe harbor (free of civil as well as criminal liability) for a torturer or other common enemy of mankind." 94 Justice Kennedy left open the possibility that serious violations of international law could meet the "touch and concern" requirement. ${ }^{95}$ Thus, it is important to note a majority of Justices may find that serious violations of international law "touch and concern" the United States with sufficient force to overcome the presumption against extraterritoriality.

In fact, in several ATS cases since Kiobel, lower federal courts have found the presumption overcome, finding that complaints sufficiently

In perhaps what was an inkling of what was to trouble the Court in Kiobel, the Court also indicated in a footnote the possibility of requiring exhaustion of claims in the country where the harm occurred. Id. at 733 n. 21 .

89. Id. at 725 .

90. The presumption against extraterritoriality is the "longstanding principle of American law 'that legislation of Congress, unless a contrary intent appears, is meant to apply only within the territorial jurisdiction of the United States." EEOC v. Arabian Am. Oil Co., 499 U.S. 244, 248 (1991) (quoting Foley Bros., Inc. v. Filardo, 336 U.S. 281, 285 (1949)). In applying this principle, courts "assume that Congress legislates against the backdrop of the presumption against extraterritoriality." EEOC, 499 U.S. at 248.

91. Kiobel v. Royal Dutch Petrol. Co., 133 S. Ct. 1659, 1669 (2013).

92. Id.

93. Id. at 1673-75 (Breyer, J., concurring).

94. Id. at 1671 .

95. Id. at 1669 (Kennedy, J., concurring). 
allege that funding or decision-making leading to the human rights violations took place in the United States. ${ }^{96}$ Thus, even though Kiobel has limited claims that can be brought pursuant to the ATS, claims will continue to be brought, making the limits on general personal jurisdiction discussed herein a critical problem for victims seeking relief under the ATS.

\section{B. Before Goodyear and Daimler, Courts Often Asserted General Personal Jurisdiction Over TNCs in ATS Cases.}

Although it was never easy to assert jurisdiction over a foreign corporation with few ties to the United States (and in fact, plaintiffs rarely attempted to do so), courts in ATS cases almost always asserted general personal jurisdiction over transnational corporations accused of human rights violations. ${ }^{97}$ In fact, before Goodyear and Daimler, foreign corporations (whether the corporation was incorporated in a different state or abroad) rarely challenged a court's assertion of general personal jurisdiction, as long as the corporation was conducting continuous and systematic business in the state where the claim was brought, including

96. Several cases have been found to survive the Kiobel "touch and concern" standard. See Al Shimari v. CACI Premier Tech., Inc., 758 F.3d 516, 520 (4th Cir. 2014), Doe v. Exxon Mobil Corp., No. CV 01-1357, 2015 WL 5042118 (D.D.C. July 6, 2015); Mwani v. Laden, 947 F. Supp. 2d 1, 5-6 (D.D.C. 2013) (finding that there is subject matter jurisdiction over the case under the ATS, but certifying this issue for appeal because the jurisdiction is one of first impression); Sexual Minorities Uganda v. Lively, 960 F. Supp. 2d 304, 310 (D. Mass. 2013) (holding that allegations were sufficient to establish jurisdiction under ATS since both crimes against humanity and aiding and abetting liability are well-established and accepted customary international law); Krishanti v. Rajaratnam, No. 2:09-CV-05395, 2014 WL 1669873 (D.N.J. Apr. 28, 2014) (finding that the court had jurisdiction because plaintiffs were suing the Rajaratnam defendants, who are U.S. citizens, for their alleged actions that occurred within the US territory); Du Daobin v. Cisco Sys., Inc., 2 F. Supp. 3d 717, 728 (D. Md. 2014) (finding that ATS claims could be brought against a defendant that has taken certain actions within the United States with respect to products that might be primarily used for violations of the laws of nations); Ahmed v. Magan, No. 2:10-CV-00342, 2013 WL 4479077 (S.D. Ohio Aug. 20, 2013) (concluding that defendant has waived his rights based on the Kiobel decision and as a permanent U.S. resident, he should be subject to the jurisdiction of the court ); In re S. African Apartheid Litig., 15 F. Supp. 3d 454, 465 (S.D.N.Y. 2014); Salim v. Mitchell, 183 F. Supp. 3d 1121, 1131-33 (2016); You v. Japan, No. 15-03257 WHA, 2015 WL 6689398 (N.D. Cal. Nov. 3, 2015), dismissed on other grounds; Shell Offshore, Inc. v. Greenpeace, Inc., No. 3:15-CV-00054-SLG, 2015 WL 3745641 (D. Alaska June 12, 2015).

97. For example, of the approximately 312 human rights cases filed against businesses or organizations between 1980, when modern ATS litigation began, and Goodyear, only nine cases were dismissed on personal jurisdiction grounds. See Kenney, supra note 83, at 1067-69, generally, and the Kenney Dataset, supra note 83]. Although this information does not reveal which defendants were foreign corporations, it does give a sense that few were dismissed on the basis of personal jurisdiction. See infra at this section for further discussion of cases and the reasons for their dismissal. 
when it was operating through a subsidiary located there. ${ }^{98}$ In addition, before Daimler, courts in ATS cases also asserted general jurisdiction over a parent TNC when such parents had U.S. subsidiaries, finding that the subsidiary was acting as an agent for the parent for purposes of personal jurisdiction. ${ }^{99}$ Other times, courts asserted general personal jurisdiction over a corporation for alleged human rights abuses by noting that a U.S.-based subsidiary was acting as a foreign parent's alter ego, and that jurisdiction over the parent should exist under a theory similar to

98. See, e.g., Complaint for War Crimes; Aiding and Abetting Extrajudicial Killing; Cruel, Inhuman, or Degrading Treatment or Punishment; Wrongful Death; and Negligence at 12, Corrie v. Caterpillar, Inc., 403 F. Supp. 2d 1019 (W.D. Wash. 2005) (No. 05-cv-05192-CMP-FOB), 2005 WL 976855 (noting that Caterpillar "does sufficient business in Washington to be considered a resident of Washington." Even though it is incorporated in Delaware with its principal place of business in Illinois, the defendant did not raise lack of personal jurisdiction in any motion to dismiss.); Sarei v. Rio Tinto, 671 F.3d 736, 744 (9th Cir. 2011) (noting that Rio- Tinto, an international mining group incorporated and based in England and Australia, conceded that the federal district court in California had general personal jurisdiction over it, given that it had substantial operations in the United States, with 47 percent of its consolidated operating assets located in North America in 1999); Doe v. Exxon, 393 F. Supp. 2d 20, 22 (D.C.C. 2005) (noting that the corporate parent, Exxon Mobile Corp., did not challenge personal jurisdiction of the District of Columbia court, even though Exxon Mobile is a New Jersey corporation with its headquarters in Irving, Texas.). See also Manook v. Research Triangle Inst., 693 F. Supp. 2d 4, 10 (D.D.C. 2010) (finding that the defendant Unity, a foreign corporation organized under the laws of Singapore with its principal base of business in Dubai, United Arab Emirates, had systematic and continuous contacts in the District of Columbia, but allowing for discovery to see whether such contacts were substantial enough). During discovery, the case settled. E-mail from Susan Burke, Plaintiffs' Counsel, Law Offices of Susan L. Burke, to author (July 13, 2016, 6:29 AM) (confirming case was settled) (on file with author).

99. Wiwa v. Royal Dutch Petrol. Co., 226 F.3d 88, 95 (2d Cir. 2000) (holding that a New York subsidiary investor relations office was an "agent" of the parent companies for purposes of jurisdiction because all of the subsidiary's time was devoted to the companies' business, the companies fully funded the subsidiary's expenses, and the subsidiary sought the companies' approval on important decisions). This decision was important, as the case ultimately settled. See Jad Mouawad, Shell to Pay \$15.5 Million to Settle Nigerian Case, N.Y. TIMEs (June 9, 2009), http://www.nytimes.com/ 2009/06/09/business/global/09shell.html?ref =global\&_r $=0$; see also Presbyterian Church of Sudan v. Talisman Energy, Inc., 244 F. Supp. 2d 289, 330 (S.D.N.Y. 2003); Presbyterian Church of Sudan v. Talisman Energy, Inc., No. 01 Civ. 9882(DLC), 2004 WL 1920978, at *2-3 (S.D.N.Y. Aug. 27, 2004) (finding that the court could assert general personal jurisdiction over Talisman given its subsidiary's presence in New York because the subsidiary was a "mere department" of the parent corporation); Bauman v. DaimlerChrysler Corp., 644 F.3d 909, 920-23 (9th Cir. 2011), rev'd, 134 S. Ct. 746 (2014) (holding that a wholly-owned U.S. subsidiary, Mercedes-Benz USA, LLC ["MBUSA"], which served as the U.S. general distributor of automobiles of the German parent manufacturer DaimlerChrysler Aktiengesellschaft (DCAG), was DCAG's agent for general jurisdictional purposes). At other times, courts have found either actual consent through the naming of a registered agent, or implied consent through the corporations' engaging in business in the state, although both theories have increasingly been rejected. See discussion infra at Part VI. 
piercing the corporate veil for liability purposes. ${ }^{100}$ These assertions of general personal jurisdiction allowed victims of human rights abuses to seek a remedy in U.S. courts under the ATS, a rare opportunity in a world with few options for remedy for such victims.

The next Part describes how Goodyear and Daimler have and will continue to severely impact victims' ability to seek remedies against TNCs that do significant business in the United States under the ATS for their roles in human rights violations (as well as other human rightsrelated causes of action, such as the ATA and Trafficking Victim's Protection Act).

\section{THE SEA CHANGE-GOODYEAR TO DAIMLER}

In Goodyear Dunlop Tires Operations, S.A. v. Brown, ${ }^{101}$ and Daimler $A G$ v. Bauman, ${ }^{102}$ the Court created a sea change in the law of general personal jurisdiction over foreign corporate defendants, thus impacting human rights victims' ability to seek remedy for human rights violations under the ATS and other human-rights related causes of action. In the decisions, the Court held that even where foreign corporations conduct systematic and continuous business in the United States, U.S. courts cannot assert general personal jurisdiction over them consistent with the Due Process Clause unless the corporations' activities are "so continuous and systematic" as to render them essentially "at home" in the forum state. ${ }^{103}$ Under Daimler, in nearly all circumstances, this will mean the corporation must be headquartered or incorporated in the forum state. ${ }^{104}$

With regard to asserting general personal jurisdiction over an outof-state corporation due to its subsidiary's (or parent's) presence in the state, the Goodyear Court suggested such might be possible if the plaintiffs could essentially "pierce the corporate veil" for purposes of jurisdiction, a test similar to that of piercing the veil for liability purposes, but opined that it would not consider the question because the

100. Exxon, 393 F. Supp. 2 d at 28 (finding that the plaintiffs had sufficiently pled that the Indonesian subsidiary, EMOI, acted as the alter ego of the parent corporation); see also Brilmayer \& Paisley, supra note 47 , at 14 (finding that to merge a parent and subsidiary for jurisdictional purposes requires an inquiry similar to that of piercing the corporate veil). Although based on different legal theories, many jurisdictions have applied the "piercing the corporate veil" test as the test for agency for jurisdictional purposes; other courts have complied a less onerous test, focusing more on the specific acts of the subsidiary. See id.

101. Goodyear Dunlop Tires Operations, S.A. v. Brown, 564 U.S. 915 (2011).

102. Daimler AG v. Bauman, 134 S. Ct. 746 (2014).

103. Goodyear, 564 U.S. at 918-19; Daimler, 134 S. Ct. at 751.

104. Daimler, 134 S. Ct. at 761. 
plaintiffs did not explicitly argue it. ${ }^{105}$ In Daimler, the Supreme Court noted that the Ninth Circuit's test for jurisdiction due to agency was less rigorous than several other jurisdictions, pointing to those jurisdictions that require piercing of the corporate veil for general jurisdictional purposes. ${ }^{106}$ But like in Goodyear, the Court passed on deciding whether, and under what circumstances, courts can assert general personal jurisdiction over a foreign corporation based on agency or alter ego theories. ${ }^{107}$ As discussed in more detail below, the Court did, however, reject what the Court viewed as the Ninth Circuit's finding of jurisdiction over a parent simply where the subsidiary's role was important to the business of the enterprise, finding such a theory too sweeping. ${ }^{108}$ It is more likely that the current Court, if it accepts any agency or alter ego theory of jurisdiction in the future, will accept only a theory of jurisdiction based on alter ego, or veil piercing of the type associating with "piercing the corporate veil" for liability purposes, ${ }^{109}$ a very difficult test to satisfy, indeed. ${ }^{110}$

\section{A. Goodyear v. Brown}

The 2011 U.S. Supreme Court decision in Goodyear Dunlop Tires v. Brown was the first significant change in Supreme Court law concerning U.S. courts' assertion of general personal jurisdiction over foreign corporations since International Shoe, with the decision significantly limiting courts' ability to assert general personal jurisdiction over TNCs. In Goodyear, families of two North Carolina children who had been killed in a French bus accident caused by defective tires sued Goodyear USA, a U.S. tire manufacturer, and three foreign subsidiaries located in Luxembourg, Turkey, and France. ${ }^{111}$ Goodyear USA did not contest general personal jurisdiction because it had plants in North Carolina and regularly conducted business there ${ }^{112}$-notably, no longer sufficient contacts for a court to assert jurisdiction after Goodyear. The foreign subsidiaries, however, did contest jurisdiction. ${ }^{113}$ None of them

105. See Goodyear, 564 U.S. at $930-31$.

106. Daimler, 134 S. Ct. at 759.

107. Id.

108. Id. at $759-60$.

109. See Goodyear, 564 U.S. at 930 ("In effect, respondents would have us pierce Goodyear corporate veils, at least for jurisdictional purposes.") (citing Brilmayer \& Paisley, supra note 47, at 14, 29-30 (merging parent and subsidiary for jurisdictional purposes requires an inquiry "comparable to the corporate law question of piercing the corporate veil"').

110. Skinner, Rethinking Limited Liability, supra note 11, at 1798.

111. Goodyear, 564 U.S. at 918.

112. Id.

113. Id. 
had direct connections to North Carolina; none were registered to do business in North Carolina; none designed, manufactured, or advertised their products in North Carolina; none solicited business in North Carolina; and none sold or shipped tires to North Carolina. ${ }^{14}$ The North Carolina court simply relied on the fact that that the subsidiaries had placed their tires in the stream of commerce without any limitation on those tires being sold in North Carolina ${ }^{115}$ - a fact that the Court correctly noted went to specific jurisdiction, not general jurisdiction. ${ }^{116}$ The North Carolina court also noted that the North Carolina plaintiffs would experience hardship if they were required to litigate their claims in France, where the injuries occurred, given that they had no ties to that country. $^{117}$

The argument for general jurisdiction over the foreign subsidiaries was not particularly compelling given the lack of connection between : them and North Carolina, where the case was brought. General personal jurisdiction over the foreign subsidiaries likely would not have been sufficient even before Goodyear, given the tests outlined in International Shoe and Helicopteros. However, the analysis reshaped general personal jurisdiction over TNCs in a significant way-by limiting general personal jurisdiction to a place where the foreign corporation was "essentially at home" in the jurisdiction. ${ }^{18}$

The Goodyear Court directly relied on International Shoe in finding that contacts had to essentially render the corporation "at home" in the : jurisdiction. $^{119}$ Of course, International Shoe does not state that a company's contacts must be so continuous and systematic to essentially render the corporation "at home" in order for a court to assert general personal jurisdiction over it; indeed International Shoe does not even use the language "essentially at home." Thus, the Court arguably mischaracterizes International Shoe by using the signal "See" when referencing the case, a signal which suggests that International Shoe directly supports the statement that a business' contacts must be so

114. Id. at 921 .

115. Id. at 919 (citing Brown v. Meter, 681 S.E.2d 382, 388-89 (N.C. Ct. App. 2009), rev'd sub nom. Goodyear Dunlop Tires Operations, S.A. v. Brown, 564 U.S. 915 (2011)).

116. Id. (internal citations omitted); see also id. at 922-27.

117. Id. at 922 .

118. Id. at 919,929 . In the case, the Court distinguished between specific jurisdiction and general jurisdiction. The Court applied the constitutional due process requirement of systematic and continuous activity for asserting personal jurisdiction even where the claim arose from the contacts-i.e., specific jurisdiction. Id. at 923 . For the specific jurisdiction, the Court noted that jurisdiction can unquestionably be asserted where the corporation's intra-state activity is continuous and systematic "and that activity [gives] rise to the episode-in-suit." Id. (citing Int'1 Shoe Co. v. Washington, 326 U.S. 310, 317 (1945)).

119. Id at 919 . 
continuous as to render the business "at home" in the state. ${ }^{120}$ Rather, Justice Ginsburg, who wrote the majority, uses the verbiage after noting that the paradigm forum for exercising personal jurisdiction over a corporation should equate to an individual's "domicile." 121

International Shoe is in fact ambiguous with regard to how "systematic and continuous" the contacts must be to give rise to general personal jurisdiction. ${ }^{122}$ Of course, it is clear that the contacts must be more systematic and continuous to justify general personal jurisdiction than specific jurisdiction when the suit does not arise from the contactsbut the case states only that the contacts must be "so substantial and of such a nature as to justify suit against it on causes of action arising from dealings entirely distinct from those activities." ${ }^{23}$ International Shoe does not hold that such places can only be where the corporation is essentially at home, or even limit it to the place of incorporation or principle place of business, even though the Court certainly could have. Moreover, the two cases Justice Ginsburg discusses, Perkins and Helicopteros, are at the two ends of a continuum of what contacts might be sufficient for general personal jurisdiction. In Goodyear, the Court had some latitude in reaching a decision on the facts of the case concerning whether the business activity of the subsidiaries was enough to allow a court to assert jurisdiction over them consistent with due process. It could easily have reached a decision finding a lack of general personal jurisdiction over the foreign subsidiaries based on current case law and in line with lower court decisions. Rather, given its analysis, the Court basically found that lower courts in the United States have been violating foreign corporations' due process rights for decades.

\section{B. The Nicastro Decision and Specific Personal Jurisdiction}

In a sister opinion issued on the same day as Goodyear, J. McIntyre Machinery, Limited v. Nicastro, ${ }^{124}$ the Supreme Court also dramatically narrowed specific personal jurisdiction over foreign corporations. The case involved a worker who injured his hand in New Jersey while using a metal-shearing machine that Defendant, R J. McIntyre Machinery, Ltd. (J. McIntyre), manufactured in England, where the company is incorporated and operates. ${ }^{125} \mathrm{Mr}$. Nicastro filed his products-liability suit in a state court in New Jersey, and J. McIntyre sought to dismiss the

120. The Bluebook: A Uniform System of Citation R. 1.2(a), at 58 (Columbia Law Review Ass'n et al. eds., 20th ed. 2015).

121. Goodyear Dunlop Tires Operations, S.A. v. Brown, 564 U.S. 915, 924 (2011).

122. Int'l Shoe, 326 U.S. at 317.

123. Id. at 318 .

124. J. McIntyre Mach., Ltd. v. Nicastro, 564 U.S. 873 (2011).

125. Id. at 878 . 
suit for lack of personal jurisdiction. ${ }^{126}$ Only one of J. McIntyre's machines ended up in New Jersey, and it did not appear the company conducted any advertising, marketing, or shipping of its products to New Jersey. ${ }^{127}$ In its decision finding New Jersey lacked personal jurisdiction, the Court held that for a court to assert specific personal jurisdiction over a foreign corporation, the corporation must have purposefully directed its product to the specific U.S. state where the court sits. ${ }^{128}$ The Court reasoned that by specifically directing its products to a specific state, the foreign corporation is intending to benefit from the protection of the particular state's laws. ${ }^{129}$ The Court found that such was not the case with J. McIntyre; it did not specifically direct its products to New Jersey. ${ }^{130}$ To hold otherwise, the Court found, would violate due process. $^{131}$

Interestingly, Justice Ginsburg, who wrote the majority opinion in Goodyear, wrote a livid dissent, wherein she argued that a court should be able to assert specific personal jurisdiction over a foreign corporation in the state where the harm occurred if the corporation markets its product to the United States as a whole rather than to a specific state. ${ }^{132}$ Notably, however, she did not consider whether the defendant's contacts with the state or the nation as a whole were systematic, substantial, and continuous, even though in dicta in Goodyear, she suggested such an analysis should occur for specific jurisdiction, citing International Shoe. ${ }^{133}$

Just as with Goodyear, Nicastro will further limit courts' assertions of jurisdiction over TNCs for torts they commit. ${ }^{134}$ This decision is part of the general narrowing of jurisdiction over foreign corporations in a manner that makes it difficult for natural persons-whether foreign or

\section{Id.}

127. Id

128. Id. at 886 .

129. Id. at 887 .

130. Id.

131. Id.

132. Id. at 905-06 (Ginsburg, J., dissenting). The Federal Rules of Civil Procedure allow the assertion of jurisdiction for a federal claim involving a transnational corporation where there is cumulatively significant activity in the United States, as long as there is not sufficiently "significant" activity in one single state to support personal jurisdiction. See FED. R. CIV. P. 4(k).

133. Goodyear Dunlop Tires Operations, S.A. v. Brown, 564 U.S. 915,924 (2011).

134. See, e.g., Kate Bonacorsi, Note, Not at Home with "At-Home" Jurisdiction, 37 FORDHAM INT'L L.J. 1821, 1853-54 (2014) (noting Nicastro's limitation of asserting personal jurisdiction over transnational corporations); SCOTT L. NELSON \& ALLISON M. Zieve, Public Citizen, InJuRy in the Stream of Commerce: Personal Jurisdiction AFTER J. MCINTYRE V. NICASTRO 11-22 (2014) (arguing that plaintiffs injured by corporations abroad have lost many rights to sue due to Nicastro, and arguing that corporations can structure themselves in order to evade litigation in the U.S.). 
U.S. citizens - to seek a remedy in U.S. courts when a cause of action for a tort exists against TNCs, which is troubling enough. But it also has implications for assertions of personal jurisdiction over foreign corporations involved in human rights violations abroad. Nicastro is important to this analysis because it is unclear how courts will apply Nicastro to those human rights cases that survive Kiobel under the theory that the case "touches and concerns" the United States where decisions leading to harm were made in the United States, or money sent from the United States resulted in the harm. ${ }^{135}$ In fact, before Nicastro, alleging that decisions leading to harm took place in the United States, or money was sent from the United States, could have supplied courts with specific personal jurisdiction over the TNC, but that may no longer be possible after Nicastro.

\section{Daimler v. Bauman}

In Daimler $A G$ v. Bauman, ${ }^{136}$ the U.S. Supreme Court further limited U.S. courts' (federal and state) assertions of general personal jurisdiction over a foreign corporation. In Daimler, the Supreme Court affirmed Goodyear's holding ${ }^{137}$ that general personal jurisdiction can only be asserted over a foreign corporation where the corporation is essentially "at home," but essentially limited "home" to either the place of incorporation or principal place of business."138 Perhaps even more importantly to human rights litigation, the Court severely restricted the use of the "agency" theory to establish jurisdiction over a foreign parent with a U.S. subsidiary ${ }^{139}$ - a significant and serious impediment to human rights litigation in the United States.

In Daimler, the plaintiffs were Argentinian residents who sued Daimler AG (Daimler), a German corporation, in U.S. district court in California for human rights violations by its Argentinian subsidiary Mercedes-Benz Argentina (MB Argentina) in Argentina, where it allegedly collaborated with state security forces that kidnapped, detained, tortured, and killed certain workers of MB Argentina. ${ }^{140}$ The plaintiffs, family members of the victims, alleged that Daimler was vicariously liable for acts of its Argentinian subsidiary. ${ }^{141}$ Plaintiffs claimed the U.S. District Court had jurisdiction over the lawsuit on two bases: first, due to

135. See discussion supra Part II.A.

136. Daimler AG v. Bauman, 134 S. Ct. 746 (2014).

137. Goodyear, 564 U.S. at $915,929$.

138. Daimler, $134 \mathrm{~S} . \mathrm{Ct}$. at $761 \mathrm{n.19}$.

139. Id. at 760-63.

140. Id. at 750-51.

141. Id. at 751-52. 
the presence and contacts of Daimler itself in California, ${ }^{142}$ and second, on the theory that the U.S. subsidiary, Mercedes-Benz USA, LLC (MB USA) acted as Daimler's agent in California, and thus, its contacts should be imputed to Daimler for purposes of jurisdiction. ${ }^{143}$ MB USA is not headquartered or incorporated in California; rather it is incorporated in Delaware with its principal place of business in New Jersey. ${ }^{144}$ However, Plaintiffs alleged that MB USA is Daimler's exclusive importer and distributor of Mercedes-Benz in the United States, and distributed those vehicles to independent dealerships throughout the United States, including California. ${ }^{145}$ The plaintiffs alleged MB USA also has multiple California-based facilities, and, inter alia, MB USA's California sales accounted for 2.4 percent of Daimler's worldwide sales. $^{146}$

The federal district court found that Daimler's own contacts with California were insufficient for the court to assert general personal jurisdiction over Daimler, and that the plaintiffs failed to establish that MB USA acted as Daimler's agent. ${ }^{147}$ The Ninth Circuit overturned the district court's decision regarding agency, holding that the district court could assert general personal jurisdiction over Daimler because MB USA was an agent for jurisdictional purposes. ${ }^{148}$ Importantly, Daimler conceded that the federal court had general personal jurisdiction over MB USA (which it might not have done in light of Goodyear) ${ }^{149}$ - and thus, the Ninth Circuit found that asserting jurisdiction over Daimler via MB USA's imputation of contacts was reasonable. ${ }^{150}$ The Ninth Circuit explained that in California, there were two ways in which the contacts of the subsidiary could be imputed to the parent-either through alter ego or agency theories, finding the latter applicable in the case. ${ }^{151}$ Before the Supreme Court decision in Daimler, a California subsidiary's contacts could be imputed to the foreign parent for purposes of asserting general personal jurisdiction over the parent, as long as the subsidiary was acting as an "agent" of the parent. ${ }^{152}$ For jurisdictional purposes, a

142. Id. at 752 .

143. Id.

144. Id.

145. Id.

146. Id.

147. Id. at 752-53 (citing the district court decisions) (internal citations omitted).

148. Bauman v. DaimlerChrysler Corp., 644 F.3d 909, 912-14 (9th Cir. 2011).

149. Daimler, $134 \mathrm{~S}$. Ct. at 758.

150. Id. at 753 (citing 644 F.3d 909 (9th Cir. 2011)). The plaintiffs did not appeal the district court's decision that Daimler's own contacts were not sufficient for the court to assert personal jurisdiction on that basis. $I d$. at 758 .

151. Bauman, 644 F.3d at 920 .

152. Harris Rutsky \& Co. Ins. Servs. v. Bell \& Clements Ltd., 328 F.3d 1122, 1134 (9th Cir. 2003). 
subsidiary corporation was considered an agent if "the subsidiary represents the parent corporation by performing services sufficiently important to the parent corporation that if it did not have a representative to perform them, the parent corporation would undertake to perform substantially similar services." 153 The Ninth Circuit went into a lengthy discussion of the General Distributor Agreement, focusing on both Daimler's control over MB USA, as well as the fact that without the subsidiary, the function of importing and distributing would have to be done by Daimler itself. ${ }^{154}$ The Ninth Circuit also found that the defendant did not meet the burden of establishing "unreasonableness" (a second fact the court explored for purposes of due process) based on a variety of factors, such as California's interest in adjudicating a human rights case, the adequacy of Argentina as a forum, and Daimler's pervasive contacts in California through its subsidiary, MB USA. ${ }^{155}$

The Supreme Court reversed the Ninth Circuit decision, holding that the lower courts could not assert general personal jurisdiction over Daimler, the parent, consistent with due process. ${ }^{156}$ After affirming Goodyear's holding that general personal jurisdiction can only be asserted over a foreign corporation where the corporation is essentially "at home," 157 the Court opined that in determining a corporation's home, a court must appraise a corporation's activities in their entirety, looking both nationwide and worldwide. ${ }^{158}$ The Court explained that a corporation cannot be at home in several locations, otherwise the new jurisdictional test would be no different than the prior "doing business" test. ${ }^{159}$ The Supreme Court then essentially limited a foreign corporation to having one home-either its place of incorporation or principal place of business, except in an "exceptional case."160 The example the Court gave of an "exceptional case" was the situation in Perkins, where the company essentially relocated most of its operations temporarily to the United States during World War II. ${ }^{161}$ The Court did not explore what other situations might be "exceptional," noting only that the defendant in the case, a German corporation, had practically no connection to

153. Bauman, 644 F.3d at 920 (quotation marks, brackets, and ellipses omitted).

154. Id. at $921-24$.

155. Id. at 924-930. The seven factors the court weighed were: the extent of purposeful interjection; the burden on the defendant; the extent of conflict with sovereignty of the defendant's state; the forum state's interest in adjudicating the suit; the most efficient judicial resolution of the dispute; the convenience and effectiveness of relief for the plaintiff; and the existence of an alternative forum.

156. Daimler AG v. Bauman, 134 S. Ct. 746, 761 (2014).

157. Goodyear Dunlop Tires Operations, S.A. v. Brown, 564 U.S. 915, 919 (2011).

158. Daimler, 134 S. Ct. at 762 n.20.

159. Id.

160. Id. at $761 \mathrm{n} .19$.

161. Id. 
California, and thus did not even come close to "approaching that level." 162

The important issue of whether the contacts of MB USA could be attributed to Daimler, the German parent, for purposes of general jurisdiction was the Court's more complex, and confusing, analysis. Although the Court technically passed on opining if the Ninth Circuit's agency analysis for jurisdictional purposes was appropriate, ${ }^{163}$ in this author's view, the Supreme Court essentially rejected the argument that the economic activities of a parent's wholly-owned subsidiary could be attributed to the parent company under an agency theory for purposes of general personal jurisdiction. ${ }^{164}$

In its analysis, the Court noted that the General Distributor Agreement between MB USA and Daimler specifically stated that the agreement did not make MB USA an agent of Daimler, and stated that MB USA had no authority to make binding obligations for or act on behalf of Daimler. ${ }^{165}$ The Court then went on to review whether there still might be attribution of contacts nonetheless. Importantly, because Daimler did not challenge the California court's assertion of personal jurisdiction over MB USA in the district court ${ }^{166}$ (it likely would have post-Goodyear), the Supreme Court assumed that the district court would have general personal jurisdiction over MB USA in analyzing whether the court could then assert personal jurisdiction over Daimler consistent with due process. ${ }^{167}$ However, it found that even if MB USA's contacts could be imputed to Daimler, Daimler still could not be found to be at home in California. ${ }^{168}$ The Court opined that if it held otherwise, Daimler could likely be sued in any jurisdiction, a sweeping jurisdictional analysis not tenable under the Constitution's Due Process Clause, and one that it rejected in Goodyear. ${ }^{169}$ The alter ego theory, where plaintiffs need to demonstrate a piercing of the corporate veil, appears to remain the only option for attribution of contacts, but the Court did not address that issue with any significance.

The purpose of this Article is not to provide an in-depth criticism or analysis of Daimler, but a few points are worth mentioning. First, the opinion's agency analysis appears circular and contradictory in that the Court assumed MB USA was at home in California, and assumed its

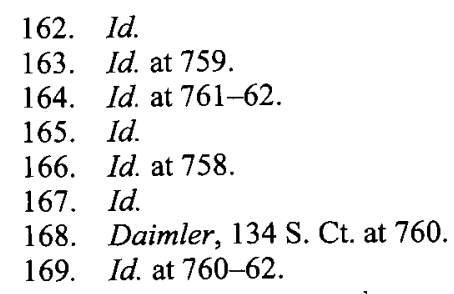


contacts (which met the level of "at home") could be imputed to Daimler, yet it still found that asserting general personal jurisdiction over Daimler was unconstitutional. Justice Ginsburg gives a hint as to why this could be in Footnote 20, stating that "[g]eneral jurisdiction instead calls for an appraisal of a corporation's activities in their entirety, nationwide and worldwide." "170 In so stating, she is likely suggesting that even if Daimler is "at home" in California due to MB USA, Daimler may be more at home in other locations. Although she does not specifically engage in a "reasonableness" discussion, she suggests it was simply unreasonable to assert jurisdiction over Daimler, and therefore, unconstitutional. In this way, Justice Ginsburg implemented a two-prong test, the second being one of reasonableness, much like the Ninth Circuit did in its decision. ${ }^{171}$

Second, what seemed to particularly trouble the Court was that the claim had no'connection to California - the injuries took place in Argentina, the plaintiffs were Argentinian, and the defendant was German. ${ }^{172}$ The Court appears to account for this lack of contacts in its unnamed reasonableness inquiry, specifically stating that asserting general personal jurisdiction in the case violates due process "given the absence of any [state] connection to the atrocities, perpetrators, or victims described in the complaint."

However, these types of concerns in a general jurisdiction analysis seemed misplaced; such concerns outside of a specific jurisdictional analysis are typically reserved for the appropriateness of subject matter jurisdiction-as in Kiobel-and Congress' prescriptive jurisdiction. In

170. Id. at 762 n. 20 .

171. Bauman v. DaimlerChrysler Corp., 644 F.3d 909, 924 (9th Cir. 2011) ("Because we hold that there is ample evidence of an agency relationship between DCAG and MBUSA, and, thus, that MBUSA's contacts with California may be imputed to DCAG, we now must turn to the second part of our test: whether the assertion of jurisdiction is "reasonable."') (internal citations omitted). Justice Sotomayor, in her Daimler concurrence, suggests this as well. Daimler, $134 \mathrm{~S}$. Ct. at 765 (Sotomayor, J., concurring).

172. Daimler, 134 S. Ct. at 751 ("The question presented is whether the Due Process Clause of the Fourteenth Amendment precludes the District Court from exercising jurisdiction over Daimler in this case, given the absence of any California connection to the atrocities, perpetrators, or victims described in the Complaint."); see also id. at 753 ("We granted certiorari to decide whether, consistent with the Due Process Clause of the Fourteenth Amendment, Daimler is amenable to suit in California courts for claims involving only foreign plaintiffs and conduct occurring entirely abroad."); id. at 761 (noting that the case is "Argentina-rooted" in determining such "exorbitant exercises" of jurisdiction); id. at 762 ("It was therefore error for the Ninth Circuit to conclude that Daimler, even with the MBUSA's contacts attributed to it, was at home in California, and hence subject to suit there on claims by foreign plaintiffs having nothing to do with anything that occurred or had its principal impact in California.").

173. Id. at 751 . 
taking these factors into consideration for general personal jurisdiction, Justice Ginsburg merges the considerations Congress has the responsibility to take into account with her general personal jurisdiction analysis. In so doing, she arguably impedes on Congress' responsibility to determine causes of action, including causes of action for extraterritorial conduct. This is especially true given that nothing impedes Congress from providing claims for extraterritorial conduct. ${ }^{174}$ Congress has numerous bases for providing for extraterritorial claims involving human rights or terror-related claims such as those brought under the ATS, the ATA, or the Trafficking Victims Protection Act. Congress arguably has the power to prohibit and provide for causes of action for such conduct under the Offenses Clause ${ }^{175}$ and the Foreign Commerce Clause. ${ }^{176}$ Moreover, while some courts have held that the "Due Process Clause prohibits the exercise of extraterritorial subject matter jurisdiction over a defendant when it would be 'arbitrary or fundamentally unfair,",177 due process for these types of claimsinternational human rights violations, human trafficking, and international terrorism-are arguably satisfied under what is known as the "protective principle," given that all potential defendants are on notice that conduct giving rise to such claims are prohibited by international law (and indeed nearly all domestic law). ${ }^{178}$

174. See EEOC v. Arabian Am. Oil Co., 499 U.S. 244, 248 (1991).

175. U.S. Const. art. $1, \S 8, \mathrm{cl} .10$ (granting Congress the power " $[\mathrm{t}] \mathrm{o}$ define and punish ... Offences against the Law of Nations"); United States v. Baston, 818 F.3d 651, 666 (11th Cir. 2016).

176. U.S. CONST. art. I, $\S 8$, cl. 3 (granting Congress the power to "regulate Commerce with foreign Nations"); Baston, 818 F.3d at 668 (Congress's power under Foreign Commerce Clause included power to regulate channels and instrumentalities of commerce between United States and other countries, and activities that had substantial effect on such commerce, including human trafficking).

177. See, e.g., Baston, 818 F.3d at 669 (citing United States v. IbarguenMosquera, 634 F.3d 1370, 1378 (11th Cir. 2011)); see also United States v. Cardales, 168 F.3d 548, 553 (1st Cir. 1999); United States v. Howard-Arias, 679 F.2d 363, 371 (4th Cir. 1982); Leasco Data Processing Equip. Corp. v. Maxwell, 468 F.2d 1326, 1334 (2d Cir. 1972) ("If Congress has expressly prescribed a rule with respect to conduct outside the United States ... a United States court would be bound to follow the Congressional direction unless this would violate the due process clause of the Fifth Amendment."), abrogated on other grounds by Morrison v. Nat'l Austl. Bank Ltd., 130 S. Ct. 2869 (2010).

178. See, e.g., Baston, 818 F.3d at 670 (finding that the TVPA complies with the "protective principle" of international law, which provides that a country may enact laws involving extraterritorial criminal conduct that "threatens its security as a state or the operation of its governmental functions" and "is generally recognized as a crime under the law of states that have reasonably developed legal systems," and noting that the citizenship of the defendant is irrelevant and that "it does not matter whether the conduct had 'an actual or intended effect inside the United States" because "[ $t]$ he conduct may be forbidden if it has a potentially adverse effect") (internal citations omitted). 
Justice Ginsburg seems to recognize this weakness by acknowledging that the Court of Appeals emphasized the fact that Congress had enacted the ATS and Torture Victims Protection Act (the other TVPA) - two causes of action which include extraterritorial conduct ${ }^{179}$ - but then noting that recent decisions of the Court had "rendered plaintiffs' ATS and Torture Victims Protect Act claims infirm." 180 Justice Ginsburg may be responding to anticipated criticism that Congress has provided for causes of action for these claims and to justify her considerations of extraterritoriality in her analysis. However, personal jurisdiction analyses should only concern whether the court can assert in personam jurisdiction, not the wisdom of Congress' decisions to provide for claims that arise abroad. Otherwise, serious constitutional issues regarding balance of power could ensue.

Justice Ginsburg also discusses international comity and notes that, before Goodyear and Daimler, the United States had very expansive personal jurisdiction, and that it potentially caused some friction with other countries. ${ }^{181}$ She argues that in the European Union (EU), a corporation can only be sued where it is domiciled or headquartered. ${ }^{182}$ However, in many situations, a plaintiff can sue a foreign corporation outside of its domicile, i.e., in the plaintiff's country, as long as the corporation is a member of another EU country. ${ }^{183}$ Additionally, EU regulations allow citizens of $\mathrm{EU}$ countries to sue foreign corporations that are not members of an EU state for, inter alia, consumer and employment claims. ${ }^{184}$ Moreover, she fails to note that the EU rule only applies to corporations of EU countries. ${ }^{185}$ In fact, each European country's own laws on jurisdiction apply to non-EU corporations, and often those jurisdictional rules can be quite broad, even broader than in the United States in many instances. ${ }^{186}$

179. Daimler AG v. Bauman, 134 S. Ct. 746, 762-63 (2014).

180. Id. at 763 (citing Kiobel v. Royal Dutch Petrol. Corp., 133 S. Ct. 1659, 1669 (2013) (finding the presumption of extraterritorial application applied to claims under the ATS); Mohamad v. Palestinian Auth., 132 S. Ct. 1702, 1705 (2012) (finding that the TVPA only applied to natural persons)).

181. Daimler, 134 S. Ct. at 763.

182. Id. (internal citations omitted).

183. Brussels I recast, supra note 16, at art. 7-24. They involve areas of law such as insurance, consumer law and employment, contract, and in rem jurisdiction, including claims involving these subjects where a plaintiff is domiciled in that member state. $I d$. Similarly, the regulations allow the courts of a member country to hear tort claims against a defendant domiciled in the EU if the "harmful event," occurred in that country. Id. at art. $7(2)$.

184. Id. at art. 18; see also id. at art. 6(1), art. 21(2).

185. Id. at pmbl. § 14; see also id. at art. 6 .

186. For example, Germany allows for assertions of general jurisdiction over parent corporations if they have any property-tangible or intangible-located in those countries, even for cases completely unrelated to the property. Bonacorsi, supra note 
Many might argue, as Justice Ginsburg suggests in her opinion in Daimler, ${ }^{187}$ that most human rights cases against TNCs for extraterritorial conduct will not survive anyway given Kiobel, so Goodyear/Daimler does little damage. But this is not true. As mentioned above, several cases have survived Kiobel, especially where courts have found that some of the decision-making which led to the harm took place in the United States. ${ }^{188}$ Moreover, Kiobel's most restrictive limitations on the ATS were imposed by a plurality, not a majority, of the Court's Justices. ${ }^{189}$ Thus, Kiobel's strict narrowing of the ATS could see an expansion as cases involving human rights reach the Court. Thus, general personal jurisdiction over TNCs will still be crucial in these human rights cases, and thus limits to general personal jurisdiction create a significant barrier to victims seeking a remedy for human rights violations that Congress provided two centuries ago, and has not repealed or amended.

\section{IMPLICATIONS OF GOODYEAR AND DAIMLER}

\section{A. Goodyear and Daimler's Effect on Human Rights Cases}

Goodyear and Daimler will greatly narrow. U.S. courts' jurisdiction over a transnational corporation where Congress has thought best to provide for a cause of action, not only in cases under the ATS, but cases under the ATA and possibly other statutes as well. In the two-and-a-half years between Goodyear and Daimler, of the approximately 54 cases filed against corporations or other entities for human rights claims, ${ }^{190}$ courts dismissed five on personal jurisdiction grounds, albeit few specifically rely directly on Goodyear. ${ }^{191}$ However, just since Daimler,

134 , at 1835,1846 (noting that recently, Germany's high court has imposed a requirement for some sort of national connection) (citing ZIVILPROZESSORDNUNG [ZPO] [CODE OF CIVIL PROCEDURE], $\S 23$, translation at http://www.gesetze-iminternet.de/englisch_zpo/englisch_zpo.html (Ger.)). The U.K. allows for general jurisdiction over non-EU businesses that are "doing business," and although courts have stated some connection to the U.K. is required, courts have not clearly defined what that entails. Bonacorsi, supra note 134, at 1841 . Still other countries allow for jurisdiction over all defendants, including foreign corporations and their subsidiaries if a court has jurisdiction over any one of them, assuming the claims are closely connected. Linda Silberman, Jurisdictional Imputation in DaimlerChrysler AG v. Bauman: A Bridge Too Far, 66 VAND. L. REV. EN BANC 123, 129 (2013).

187. Daimler, 134 S. Ct. at 763.

188. See supra note 96.

189. See supra note 93.

190. See Kenney Dataset, supra note 83.

191. Id. The cases dismissed included Tymoshenko v. Firtash, No. 11-CV-2794 KMW, 2013 WL 1234943, at *2-8 (S.D.N.Y. March 27, 2013) (dismissing case, inter alia, against corporations and individuals due to insufficient contacts within the United States); Abelesz v. OTP Bank, 692 F.3d 638, 646 (7th Cir. 2012) (dismissing action 
courts have dismissed more cases against TNCs for human rights claims for lack of personal jurisdiction. ${ }^{192}$

One case that may have survived and thus offered victims a chance for a remedy had it not been for Goodyear and Daimler is the 2014 case of Krishanti v. Rajaratnam. ${ }^{193}$ The case involved claims of aiding and abetting terrorism and crimes against humanity under the ATS against individual defendants and the Tamil Rehabilitation Organization (TRO). TRO is a Sri Lankan NGO, with a branch in Maryland, which the plaintiffs alleged supplied substantial funds to Liberation Tigers of Tamil Elam (LTTE), a U.S.-designated terrorist organization, which carried out terror attacks in Sri Lanka. ${ }^{194}$ The plaintiffs alleged that the LTTE, with help from TRO, engaged in suicide bombings and other murderous attacks on innocent civilians intended to intimidate or coerce a civilian population. ${ }^{195}$. In November of 2007 , the United States Treasury Department described TRO as a "charitable organization that acts as a front to facilitate fundraising and procurement for the LTTE," and noted that the branch in Maryland was a larger source of funds to LTTE than any other TRO branch. ${ }^{196}$

One of the primary issues in the case was whether the court had general personal jurisdiction over TRO in New Jersey, the court having rejected specific jurisdiction over TRO. ${ }^{197}$ In addition to the branch in

against Hungarian banks for lack of personal jurisdiction); In re Terrorist Attacks on Sept. 11, 2001, 840 F. Supp. 2d 776, 780-91 (S.D.N.Y. 2012) (dismissing ATS/TVPA case against a Saudi Arabian construction company for lack of personal jurisdiction); Ivanovic v. Overseas Management Co., No. 11-80726-Civ, 2011 WL 5508824, at *3-4 (S.D. Fla. Nov. 9, 2011) (dismissing case due to lack of personal jurisdiction over eight of eleven defendants); Weisskopf v. United Jewish Appeal, 889 F. Supp. 2d 912, 919-30 (S.D. Tex. 2012) (dismissing case against New York nonprofit for lack of personal jurisdiction in Texas (and no nationwide service)).

192. Krishanti v. Rajaratnam, No. 2:09-CV-05395 JLL, 2014 WL 1669873, at*7 (D.N.J. 2014) (holding that there was no general jurisdiction over the NGO for ATS and other claims for aiding and abetting a foreign terrorist organization, despite frequent contacts, given that the NGO was not "at home" in New Jersey, relying on Goodyear and Daimler); William v. AE Corp., 28 F. Supp. 3d 553, 563-70 (E.D. Va. 2014) (describing a lack of general personal jurisdiction over subsidiary under Goodyear analysis). Although not a human rights case, see also Keeley v. Pfizer, Inc., No. 4:15CV00583 ERW, 2015 WL 3999488, at *2-4 (E.D. Mo. July 1, 2015) (dismissing case brought in Missouri against Pfizer, a Delaware corporation with its principal place of business in New York, for birth defects related to Pfizer drug Zoloft, for lack of both general and personal jurisdiction, relying on Goodyear and Daimler).

193. Krishanti, $2014 \mathrm{WL} 1669873$, at *1.

194. Id. at *1.

195. Id. at *1, *2.

196. Id. at *1.

197. Id. at *5. The court rejected specific jurisdiction because it found that the injuries did not arise from TRO's activities in New Jersey, employing a "but for" test. Id. at $* 8$. 
Maryland, TRO had an office in New Jersey, ${ }^{198}$ which the plaintiffs alleged operated as a de facto headquarters for TRO's business activities within New Jersey; the address, phone number, and fax number of the New Jersey office were regularly used to promote TRO's activities within New Jersey; TRO raised a substantial amount of money within New Jersey between 1997 and 2005; a number of TRO events and fundraisers were organized in New Jersey at least once a year between 1999 and 2005, each time renting a venue, taking out insurance, marketing, and recruiting volunteers, all in New Jersey; and TRO's English-language website operated from New Jersey. ${ }^{199}$

After reviewing all of these contacts, the judge found he could not assert general personal jurisdiction over TRO, specifically relying on Goodyear and Daimler, because the contacts were not so continuous and systematic as to render TRO "at home" in New Jersey. ${ }^{200}$ Prior to Goodyear and Daimler, it is possible, even likely, that the court would have found it had personal jurisdiction over TRO, given its systematic and continuous operations in New Jersey. The issue of personal jurisdiction was particularly important because the court found that it had subject matter jurisdiction over the case, even in light of Kiobel, because most of the alleged actions occurred in the United States. ${ }^{201}$ Moreover, the court rejected motions to dismiss on the grounds of forum non conveniens and exhaustion of remedies. ${ }^{202}$ Thus, had the court found it had personal jurisdiction over TRO, the case against TRO would likely have gone to trial. ${ }^{203}$

Moreover, nearly all of the cases discussed in Part II, examples of courts' assertions of general personal jurisdiction over TNCs in human rights cases, would likely not have survived under Goodyear and Daimler, resulting in victims failing to obtain remedy, or even the possibility of seeking a remedy. Cases of particular importance include Doe v. Exxon, ${ }^{204}$ Manook v. Research Triangle Institute, ${ }^{205}$ and Wiwa $v$.

198. Id.

199. Id. at *5.

200. Id. at *6-7.

201. Id. at *10-11.

202. Id. at *14.

203. Krishanti, 2014 WL 1669873, at*1. The case against two individual defendants, dual U.S. and Sri Lankan citizens, survived, but it is unclear whether such individuals have the resources to pay any damage award. See generally id.

204. Doe v. Exxon, 393 F. Supp. 2d 20 (D.D.C. 2005). Although Exxon is a U.S. corporation, it was sued in D.C., where it was not headquartered or incorporated. Moreover, the case against a subsidiary was allowed to proceed under a type of alter-ego theory, which likely would not have survived Daimler. See supra note 100.

205. Manook v. Research Triangle Inst., 693 F. Supp. 2d 4 (D.D.C. 2010). 
Royal Dutch Petroleum Shell. ${ }^{206}$ For example, Doe v. Exxon has thus far survived motions to dismiss based on Kiobel, and is pending in D.C. District Court. ${ }^{207}$ Also, the courts' assertion of general personal jurisdiction was critical for the victims in Manook, the case involving claims against a government contractor and a private security firm (Unity) where security personnel allegedly shot and killed Iraqi citizens given that the case ultimately settled, ${ }^{208}$ allowing victims to receive compensation they may not have otherwise been able to receive, at least against Unity. It is unlikely the case against Unity would have survived a motion to dismiss based on Goodyear and Daimler, even with the extensive contacts and business within the District of Columbia. This case particularly demonstrates Daimler's impact because the ATS claims against Unity and the government contractor would likely have survived Kiobel, given that Unity's work was pursuant to a contract with the U.S. government for security protection ${ }^{209}$ and thus "touched and concerned" the United States.

Similarly, Wiwa v. Royal Dutch Petroleum Shell would likely have been dismissed under Goodyear and Daimler, depriving victims of compensation, given that Shell agreed to settle the case in 2009. ${ }^{210}$ And of course, Daimler itself would likely have survived, although Kiobel's impact on the case is unknown.

Although there has not yet been an avalanche of cases dismissed for lack of personal jurisdiction that would have otherwise survived before Goodyear and Daimler, more will surely be coming. ${ }^{211}$ Moreover, there are many cases that plaintiffs likely have decided not to file against TNCs in human-rights actions in the wake of Goodyear and Daimler, and thus the cases have had a chilling effect. In fact, practitioners have reported that due to Goodyear and Daimler, they are simply not filing certain human rights cases against foreign corporations or subsidiaries,

206. Wiwa v. Royal Dutch Petrol. Co., 226 F.3d 88 (2d Cir. 2000). See supra discussion at Part II.B.

207. See supra note 96 .

208. See supra note 98 .

209. Manook, 693 F. Supp. 2d at 10.

210. See supra note 99. This case might have been dismissed pursuant to Kiobel, but such is speculation.

211. One pending human rights case on which Goodyear and Daimler might have significant impact is John Doe v. Nestle, a case involving forced Malian child labor in the preparation of Nestle products. See Plaintiffs' Second Amended Complaint, John Doe v. Nestle, 2:05-CV-05133-SVW-MRW (C.D. Cal. July 14, 2016). On March 3, 2017, the district court dismissed the case orally under Kiobel, finding that none of the claims "touch and concern" the United States with sufficient force. Doe v. Nestle, 2:05-cv05133-SVW-MRW (C.D. Cal. March 3, 2017). 
even cases that might survive Kiobel, due to lack of general personal jurisdiction over the offending foreign corporation. ${ }^{212}$

\section{B. Goodyear's and Daimler's Effect on Other Human-Rights Related Claims}

In addition to ATS cases, there have been several other human rights-related cases dismissed or otherwise impacted due to Goodyear and Daimler's new restriction on general personal jurisdiction. One area that has already been implicated by the restricted personal jurisdiction are civil claims brought by families of terrorism victims under the AntiTerrorism Act, ${ }^{213}$ in which Congress has specifically provided for a cause of action for terrorism claims, including extraterritorial claims. ${ }^{214}$ U.S. courts have recently dismissed several cases brought under the ATA specifically due to Goodyear and Daimler ${ }^{215}$ that would have otherwise survived, impacting families' and victims' ability to obtain a remedy for these violations. Courts have also recently dismissed cases involving corruption and conspiracy due to Daimler's "at home" requirement. ${ }^{216}$

212. Skinner et al., The Third Pillar, Access to Judicial Remedies for Human Rights Violations by Transnational Business 20 (Int'l Corp. Accountability Roundtable, 2013), http://icar.ngo/wp-content/uploads/2013/02/The-Third-Pillar-Access-to-JudicialRemedies-for-Human-Rights-Violation-by-Transnational-Business.pdf (citing consultations with several U.S. human rights practitioners) (last accessed Oct. 20, 2016).

213. 18 U.S.C. $\$ 2333$ (2012).

214. 18 U.S.C. $\S 2332$ (b)(e) (acts of terrorism transcending national boundaries); 18 U.S.C. $\$ 2339$ (b)(d) (providing material support or resources to designated foreign terrorist organizations); 18 U.S.C. $\S 2339$ (d)(b) (receiving military-type training from a foreign terrorist organization).

215. See, e.g., Sokolow v. Palestine Liberation Org., No. 04 CV 00397(GBD), 2011 WL 1345086, at *1 (S.D.N.Y. March 30, 2011), dismissed sub nom. Waldman v. Palestine Liberation Org., 835 F.3d 317 (2d Cir. 2016); Estate of Klieman v. Palestinian Auth., 82 F. Supp. 3d 237, 239-40 (D.D.C. 2015); see also Leibovitch v. Islamic Republic of Iran, 188 F. Supp. $3 d 734$ (N.D. Ill. 2016) (finding it did not have personal jurisdiction over a foreign bank for purposes of discovery, even though it would have before Daimler, leaving the plaintiffs unable to collect a default judgment); Simowitz, supra note 10, at 24-25 (noting the impact of Daimler on ATA cases).

It should be noted, however, that some courts have found personal jurisdiction over defendants in terrorism-related cases post-Daimler, under specific jurisdiction theories. See, e.g., Licci v. Leb. Can. Bank, 732 F.3d 161, 174 (2d Cir. 2013); Weiss v. Nat'1 Westminster Bank PLC, 176 F. Supp. 3d 264, 281, 289 (E.D.N.Y. 2016); Strauss v. Crédit Lyonnais, S.A., 175 F. Supp. 3d 3, 23 (E.D.N.Y. 2016).

216. For example, in the pending case of Reich v. Lopez, 38 F. Supp. 3d 436, 456, 458-59 (S.D.N.Y. 2014) involving RICO, conspiracy, and related torts against executives of foreign corporation, the court found that the plaintiffs failed to make a prima facie showing of general jurisdiction over two of the individual defendants given Daimler's "at home" requirement. Id. at 458-59 (the court, however, allowed jurisdictional discovery to further establish personal jurisdiction). Another example is In re LIBOR-Based Fin. Instruments Antitrust Litigation, No. 11-MDL-2262-NRB, 2015 WL 6243526, at *1 (S.D.N.Y Oct. 20, 2015), a case involving foreign banks that engaged in interest rate 
There are likely to be even more implications of Goodyear and Daimler under other claims, including the Trafficking Victims Protection Act, which provides a cause of action against perpetrators, including anyone who knowingly benefits from trafficking that affects international commerce. $^{217}$ The TVPA's civil remedy exists for violations of the TVPA, and Congress intended that causes of actions under the TVPA include extraterritorial violations. ${ }^{218}$ If a victim, including one who is trafficked in the United States, brings suit against a foreign corporation under the TVPA, including against a TNC doing significant business in the United States, the victim may well be out of luck even though Congress intended such victims to be able to obtain a remedy. Indeed, at least one case suggests that personal jurisdiction may be an issue in future TVPA litigation. ${ }^{219}$

\section{Narrow Jurisdiction Over TNCs Stands in Stark Contrast to Transient, or "Tag," Jurisdiction over Individuals.}

It is important to note that natural persons can be subjected to a court's jurisdiction simply by being served while within the state in which the court sits - even if just passing through on one occasionsomething called "transient" (or "tag") ${ }^{220}$ jurisdiction. ${ }^{221}$ In fact, courts

manipulation, where the court found it could not assert general personal jurisdiction over the defendants in accordance with Daimler and Goodyear, despite their presence and operation in the United States because they could not be considered "at home" there. Id. at *24-27.

Others have raised concerns of Daimler's implication on other types of cases as well, such as arbitration under the FSIA and patent infringements. See, e.g., Simowitz, supra note 10 , at $40-41$.

217. 18 U.S.C. $\S 1595$; see also 18 U.S.C. $\S \S 1583,1590 ; 18$ U.S.C. $\S 1584 ; 18$ U.S.C. $\S \S 1581,1589,1591,1596$ (setting forth violations that can be sued upon, without any extraterritorial limits).

218. See, e.g., United States v. Baston, 818 F.3d 651, 667 (11th Cir. 2016) (noting that the TVPA applies extraterritorially); see also Sonia Merzon, Note, The Extraterritorial Reach of the Trafficking Victims Protection Act, 39 GEO. WASH. INT'L L. REV. 887, 913-15 (2007) (documenting how Congress intended the TVPA to apply to extraterritorial conduct).

219. See Kiwanuka v. Bakilana, 844 F. Supp. 2d 107, 121-22 (D.D.C. 2012) (holding, in dicta, that although the case involved an individual defendant, the court could assert personal jurisdiction over him even though he was physically in Tanzania, given that "he had attended the George Washington University School of Business in Washington, D.C.," which the court found established a sufficient contact) (citing Int'1 Shoe Co. v. Washington, 326 U.S. 310,316 (1945)).

220. See Martinez v. Aero Caribbean, 764 F.3d 1062, 1067 (9th Cir. 2014) (noting that this kind of jurisdiction is often referred to as "tag jurisdiction").

221. The Federal Rules of Civil Procedure specifically authorize jurisdiction where there has been personal service of a summons and complaint upon an individual physically present within a judicial district of the United States, and the Supreme Court found such complied with due process in Burnham v. Superior. 
have found personal jurisdiction over nonresident individual defendants in human rights cases, such as the self-proclaimed president of Serbia, proper for having served the defendant while he was temporarily in the jurisdiction. ${ }^{222}$ However, nearly all courts have found that tag jurisdiction does not apply to corporations. ${ }^{223}$ The argument is that unlike natural persons, who can physically be in one place and thus a court can physically assert power over him or her, corporations can only act through their agents and can be in many places simultaneously. ${ }^{224}$ As Justice Scalia noted in Burnham, ${ }^{225}$ corporations "have never fitted comfortably in a jurisdictional regime based primarily upon 'de facto power over the defendant's person,", ${ }^{226}$ citing International Shoe.

However, the reasoning that the various Justices who wrote plurality opinions in Burnham gave for justifying tag jurisdiction over individuals also holds true for corporations. Justice Scalia wrote the plurality opinion, noting that transient jurisdiction had been around since

Court, 495 U.S. 604 (1990). See FED. R. CIV. P. 4(e)(2). Notably, the same section also allows service of summons on an agent authorized to receive service, but after Goodyear and Daimler, that provision is essentially invalid with regard to foreign corporations.

222. See Kadic v. Karadžić, 70 F.3d 232, 247 (2d Cir. 1994) (upholding personal jurisdiction over Defendant Karadžić, who was served while visiting New York, on the basis of Burnham, and finding that "personal service comports with the requirements of due process for the assertion of personal jurisdiction"), cert. denied, 518 U.S. 1005 (1996).

223. See, e.g., Martinez, 764 F.3d at 1067-69 (holding that tag jurisdiction over the defendant does not extend jurisdiction to the defendant's corporation, despite the defendant acting on behalf of the corporation at the time of service of process, and that International Shoe and all Supreme Court decisions since have assumed tag jurisdiction does not apply to corporations); Siemer v. Learjet Acquisition Corp., 966 F.2d 179, 18283 (5th Cir. 1992) (holding that Burnham did not authorize tag jurisdiction based on instate service on a corporation's registered agent). But see N. Light Tech., Inc. v. N. Lights Club, 236 F.3d 57, $63 \mathrm{n} .10$ (1st Cir. 2001) (stating in a footnote that service on a corporation's president conferred general personal jurisdiction over the corporation, without explaining its decision or citing any supporting case). In First Am. Corp. v. Price Waterhouse LLP, 154 F.3d 16 (2d Cir. 1998), the court held that tag jurisdiction over PW-UK, a "worldwide" company was proper regarding a third party subpoena because PW-UK's partner was properly served within the forum, relying on the notion that service on one partner is service upon the partnership. See id. at 23. It does not appear that the court considered the argument that because Price Waterhouse was a corporation, Burnham did not apply. Moreover, Price Waterhouse addressed a third-party subpoena, not service of a summons and complaint. A later opinion in a federal district court within the Second Circuit, Estate of Unger v. Palestinian Auth., 400 F. Supp. 2d 541 (S.D.N.Y. 2005), clarified that tag jurisdiction did not apply to corporations, noting that "'tag' jurisdiction-personal service on an individual within the state-remains a valid method of acquiring personal jurisdiction over an individual, though not over a corporation through the persons of its officers," distinguishing Price Waterhouse. Id. at 553.

224. See Martinez, 764 F.3d at 1067-69; Siemer, 966 F.2d at 182-83.

225. Burnham v. Superior Court, 495 U.S. 604 (1990).

226. Id. at 610 n.1 (Scalia, J., plurality opinion) (quoting Int'l Shoe Co. v. Washington, 326 U.S. 310, 316 (1945)). 
the adoption of the $14^{\text {th }}$ Amendment and was too ingrained in the American legal system to be considered a violation of due process. ${ }^{227}$ This can also be said of corporations. Before Goodyear and Daimler, it was ingrained in the legal system that courts could assert jurisdiction over corporations doing business, and after International Shoe, continuous and systematic business in the state. As Justice Scalia noted, every nation ought to be able to "rightfully exercise jurisdiction over all persons within its domains."228

Justice Brennan wrote another opinion in Burnham, joined by three justices. $^{229}$ He rejected Justice Scalia's historical justification, noting that asserting personal jurisdiction must meet modern due process. ${ }^{230}$ However, he found the assertion of jurisdiction in the case proper because (1) individual defendants are on notice that they could be served while in the state; (2) individuals traveling to the state are subjecting themselves to the protection of the state, so asserting jurisdiction over them is fair; (3) modern technology makes it less burdensome for nonresident defendants to defend themselves in another state's courts; and (4) the doctrine of forum non conveniens was always available to the defendant. $^{231}$ The same is true of corporations. Just as courts ought to be able to assert general personal jurisdiction over natural persons who are served while "passing through" the court's jurisdiction, courts ought to be able to assert general personal jurisdiction over transnational corporations that are served while "doing business" in a state. This difference of a courts' ability to assert jurisdiction over individuals "just passing through" versus TNCs highlights the unfairness of current jurisdictional doctrine. This is true even though, arguably, such individuals would have a much more difficult time defending a case outside their domicile than a transnational corporation doing significant business in a particular state.

227. Id. at 622 .

228. Id. at 611 (quoting Joseph StORY, COMMENTARIES ON THE CONFLiCt OF LaWS, FOREIGN AND DOMESTIC $\S 543$ (3d ed. 1846)).

229. Id. at 628 (Brennan, J., concurring).

230. Id. at 632 .

231. Id. at 632-39. 


\section{MORE EXPANSIVE PERSONAL JURISDICTION OVER TNCS IS REASONABLE AND FAIR.}

\section{A. Harmed Individuals Often Have a Difficult Time Accessing}

Remedies in Host Countries for Human Rights Violations, Thereby Absorbing All the Costs While TNCs Benefit.

While most TNCs benefit host countries through direct investment, creation of infrastructure, increased employment, and decreased poverty, ${ }^{232}$ a few others act in violation of international human rights or environmental laws, either directly, vicariously, or in concert with government security forces, local police, state-run businesses, or local businesses. Such behavior often wreaks havoc on local, vulnerable communities. Where such behavior occurs in countries with weak and fragile governments and judiciaries, the victims of these violations are often unable to obtain any compensation for their injuries against a TNC, whether it is the parent or a subsidiary operating in the host country.

First, many countries hosting subsidiaries that engage in extraction or other industries have a high potential for human rights abuses, but have ineffectual and corrupt judicial systems, or no mechanisms for victims harmed by businesses' actions to seek or obtain redress. ${ }^{233}$

232. See David Shea Bettwy, Human Rights and Wrongs of Foreign Direct Investment: Addressing the Need for an Analytical Framework, 11 RICH. J. GLOBAL L. \& Bus. 239, 243, 249-51 (2012) (noting that FDI produces socio-economic benefits, environmental benefits, and human rights benefits).

233. See Catherine J. Boggs, Project Management: A Smorgasbord of International Operating Risks $\S 3.0$ (Rocky Mtn. Min. L. Inst., Paper No. 13, 2008) (describing the challenges corporations face "in countries where bribery and corruption are endemic and appear firmly ensconced as a part of customary business practices"); Jodie A. Kirshner, Why is the U.S. Abdicating the Policing of Multinational Corporations to Europe?: Extraterritoriality, Sovereignty, and the Alien Tort Statute, 30 BERKELEY J. INT'L L. 259, 266-67 (2012) (noting how many host countries often lack functioning legal systems or may not have sufficient resources to bring multinationals to justice). The fact that many host countries involved in the extraction industry have corrupt or ineffective judicial systems, and that human rights are often violated with impunity, is also confirmed by the U.S. Department of State. See generally Country Reports on Human Rights Practices for 2013, U.S. Dep'T of State, Bureau of Democracy, H.R. \& Lab., (2013), https://www.state.gov/j/drl/rls/hrrpt/2013humanrightsreport/ (evaluating human-rights practices in various countries). For example, the report for the Democratic Republic of the Congo lists "lack of an independent and effective judiciary; and impunity throughout the country for many serious abuses, including unlawful killings, disappearances, torture, rapes, and arbitrary arrests and detention" as two of the country's three most severe human rights problems. U.S. DeP'T OF STATE, BUREAU OF DEMOCRACY, H.R. \& LAB., DEMOCRATIC REPUBLIC OF THE CONGO 2013 HUMAN RIGHTS REPORT 1 (2013). The report for Nigeria notes that "[i]mpunity remained widespread at all levels of government," and notes various issues: that political leaders influenced the judiciary, particularly at the state and local levels; that understaffing, underfunding, inefficiency, and corruption continued to prevent the judiciary from functioning adequately; that judges frequently fail 
Second, sometimes there is simply no statutory or common law basis to bring a claim. ${ }^{234}$ Third, it might be that victims bring a suit against the subsidiary in the host state and receive a verdict, but are then unable to collect due to lack of funds, underfunding, or bankruptcy. ${ }^{235}$ Fourth, due to the complexity of corporate structure, sometimes victims are simply unable to identify which subsidiary is operating in their area and, thus, are unable to determine which entity to bring a claim against. ${ }^{236}$ What can be even more confusing is that the subsidiary may be using the "logo" of the parent company, leading to confusion about the entity operating in the area and thus responsible, as has been reported to have occurred in Nigeria with Shell (trucks owned by the subsidiary had the Shell logo on the side) in Kiobel. ${ }^{237}$

Fifth, victims may have legitimate fears of retaliation by the business or the members of the community if they bring a claim. ${ }^{238}$. Finally, victims may also find that bringing a lawsuit may be too costly given lack of contingency fee arrangements and loser pay rules, or they may simply be unable to find a lawyer in that country willing to bring a

to appear for trials, often because they were pursuing other sources of income and sometimes because of threats against them; and that there was a widespread perception that judges were easily bribed and litigants could not rely on the courts to render impartial judgments. U.S. DEP'T OF STATE, BUREAU OF DEMOCRACY, H.R. \& LAB., NIGERIA 2013 HUMAN RIGHTS REPORT 2, 12-13 (2013). The report on Guatemala notes that "[p]rincipal human rights abuses included widespread institutional corruption, particularly in the police and judicial sectors" and "[t] $]$ he judicial system failed to provide fair or timely trials due to inefficiency, corruption, insufficient personnel, and intimidation of judges, prosecutors, and witnesses." U.S. DEP'T OF STATE, BUREAU OF Democracy, H.R. \& LAB., Guatemala 2013 Human Rights Report 1, 7 (last updated March 18, 2014).

234. See Skinner, Beyond Kiobel, supra note 11, at 227 (explaining how "[c]hoice of law" principles can "create unforeseen barriers to recovery").

235. Id. at 233-34.

236. See id. at 244 ("For example, parent companies over which the courts have jurisdiction may deny any involvement in subsidiaries' actions, yet often will not produce information regarding the subsidiaries, including information regarding their relationships to the subsidiaries."); see also Skinner, Rethinking Limited Liability, supra note 11 , at $1802 \mathrm{nn} .113-14$.

237. Kiobel v. Royal Dutch Petrol. Co., 133 S. Ct. 1659, 1662 (2013); Skinner, Rethinking Limited Liability, supra note 11, at 1802 n.114 (noting reports of how trucks of Shell's Nigerian subsidiary had the Shell logo on their side).

238. See Skinner, Beyond Kiobel, supra note 11, at 172, 231-34 (discussing how the potential for "unwarranted counterclaims or retaliatory claims," id. at 232 , can dissuade victims from bringing human rights claims). 
suit in court. ${ }^{239}$ All of these factors converge to create a situation where victims are likely to have little recourse in their own countries. ${ }^{240}$

Yet, it is clear that TNCs gain enormous financial benefits by operating globally, ${ }^{241}$ especially when operating within countries that have few regulatory mechanisms to ensure corporations and their subsidiaries are complying with human rights and environmental norms and laws. ${ }^{242}$ While these transnational corporations stand to benefit greatly from their work in less developed or developing countries, it is often the local, most vulnerable populations and communities - often nonconsenting to the development-who absorb most of the costs associated with this economic activity in the form of lower labor and regulatory costs, environmental damage, and civil and human rights violations. ${ }^{243}$ Given the power of TNCs and the increasing difficultly to

239. See $i d$. at 172,233 (noting how the "loser pays" system common in host countries can serve as a barrier to representation).

240. See id. at 172 (recognizing that "victims ... would much rather bring cases in the host countries as long as the judiciary was fair, stable, and effective, and the victims felt safe bringing such claims").

241. See Daniel Chow, Counterfeiting as an Externality Imposed by Multinational Companies on Developing Countries, 51 VA. J. INT'L L. 785, 816-17 (2011) (describing advantages of low labor costs and lenient regulatory regimes); J. Clifton Fleming, Jr. et al., Worse Than Exemption, 59 EMORY L.J. 79, 84-85 (2009) (describing how their use of foreign subsidiaries provides U.S. resident corporations with "overly generous tax benefits" and providing examples); Christopher H. Hanna, Corporate Tax Reform: Listening to Corporate America, 35 IowA J. CORP. L. 283, 298-99 (2009) (describing significant tax advantages of global business and operating through foreign subsidiaries, such as the tax advantages of deferral of income earned by a foreign subsidiary); Christopher H. Hanna, The Real Value of Tax Deferral, 61 FLA. L. REV. 203, 231-33 (2009) (describing additional tax-related benefits of transnational businesses, such as advantageous accounting rules).

242. See Chow, supra note 241; Rhys Jenkins, Corporate Codes of Conduct: SelfRegulation in a Global Economy, 2 TECH., BUS. \& Soc'Y 1, 1 (2001) (describing the major shift in the "will and ability" of developing countries to control the activities of multinational corporations (MNCs), and the emphasis on attracting them over regulating them).

243. See, e.g., David W. Leebron, Limited Liability, Tort Victims, and Creditors, 91 COLUM. L. REV. 1565, 1584-87, 1613-23, 1637-40 (1991) (discussing corporations' externalization of costs to reap benefits from their subsidiaries' potentially abusive conduct in host country); Kiarie Mwaura, Internalization of Costs to Corporate Groups: Part-Whole Relationships, Human Rights Norms and the Futility of the Corporate Veil, 11 J. INT'L BUS. \& L. 85, 85-86 (2012) (explaining how victims of human rights abuses often absorb the costs of those abuses); Elizabeth Barrett Ristroph, How Can the United States Correct Multi-National Corporations' Environmental Abuses Committed in the Name of Trade?, 15 IND. INT'L \& COMP. L. REV. 51, 53-54 (2004) (noting corporations externalize the costs of doing business while enjoying the benefits); Mark J. Roe, Corporate Strategic Reaction to Mass Tort, 72 VA. L. REV. 1, 39-56 (1986) (examining the practice of externalizing the risks of a subsidiary operating in a host country to allow the parent corporation to avoid liability as a result of actions taken by subsidiary); Robert B. Thompson, Unpacking Limited Liability: Direct and Vicarious Liability of Corporate Participants for Torts of the Enterprise, 47 VAND. L. REV. 1, 29-39 (1994) (discussing 
hold those few that commit human rights violations accountable for harm, ${ }^{244}$ there simply needs to be a paradigm shift regarding numerous doctrines, including personal jurisdiction. Where the parent or lead company is headquartered or domiciled in the United States, victims may be able to bring a claim against the parent if the victims can establish the parent's responsibility. But the difficulty exists where the parent or lead company is not headquartered or domiciled in a country that would allow the victims to bring a claim. Where such TNCs do business in the United States, expansive jurisdictional rules would allow victims to seek a remedy in the United States against these TNCs where Congress has otherwise provided for causes of action allowing victims to seek such a remedy for extraterritorial conduct.

Although a similar paradigm shift is also needed in Europe and elsewhere, such jurisdictional expansion is particularly important in the United States. This is because victims face even greater challenges in seeking and obtaining a remedy in Europe or Canada, for a variety of reasons. These include a lack of causes of action for human rights violations, ${ }^{245}$ lack of contingency fees, loser pay rules, ${ }^{246}$ damage

corporations' externalization of costs to reap benefits from their subsidiaries' potentially abusive conduct in host country); Meredith Dearborn, Comment, Enterprise Liability: Reviewing and Revitalizing Liability for Corporate Groups, 97 CALIF. L. REV. 195, 20507 (2009) (noting the large benefits corporations gain from host country's subsidiaries' risky conduct while only bearing some of the costs).

244. For example, in Kiobel, the Court significantly limited accountability of transnational corporations by greatly limiting U.S. federal courts' subject matter jurisdiction over violations of international human rights law that occurred abroad. See discussion supra Part II.A. In another U.S. Supreme Court case, Mohamad v. Palestinian Auth., 566 U.S. 449, 454 (2012), the Supreme Court held that claims brought under the Torture Victim Protection Act (TVPA) applied only to individuals-natural personsand not corporations. In non-human rights cases, the Supreme Court has issued other opinions which enhance the power of corporations over individuals, such as the decisions in Citizens United v. FEC, 558 U.S. 310 (2010) and Hobby Lobby Stores, Inc. v. Sebelius, 723 F.3d 1114 (10th Cir. 2013), aff'd sub nom. Burwell v. Hobby Lobby Stores, Inc., 134 S. Ct. 2751 (2014). See also Adam Liptak, Chief Justice's Report Praises Limits on Litigants' Access to Information, N.Y. TIMES (Dec. 31, 2015), http://www.nytimes. $\mathrm{com} / 2016 / 01 / 01 /$ us/politics/chief-justices-report-praises-limits-on-claimants-access-toinformation.html?_r $=0$ (discussing Chief Justice Roberts's praise of the limits on discovery in favor of corporations).

245. Skinner, Beyond Kiobel, supra note 11, at 193-95. The U.K. has seen some success in human rights claims being litigated as common law torts, which is the only real avenue available in most of Europe and Canada. See Michael D. Goldhaber, Corporate Human Rights Litigation in Non-U.S. Courts: A Comparative Scorecard, 3 U.C. IRVINE L. REV. 127, 130-34 (2013) (noting U.K. cases filed as torts). See also Kirshner, supra note 233, at 279-82 (noting tort actions in the United Kingdom, the Netherlands, Germany, and Switzerland).

One exception is Switzerland where, in theory, it is possible for courts to entertain claims against Swiss businesses for violations of international law. See Gypsy Int'l Recognition and Comp. Action (GIRCA) v. IBM, Bundesgericht [BGer] [Federal Supreme Court] Dec. 22, 2004, 131 ENTSCHEIDUNGEN DES SCHWEIZERISCHEN 
formulas that result in less monetary relief, ${ }^{247}$ shorter statutes of limitations, ${ }^{248}$ limited ability for collective action, ${ }^{249}$ and more restrictive discovery rules. ${ }^{250}$ Given the ATS and the relief it offers, and the generally more plaintiff-friendly legal culture in the United States, such limitations in Europe and Canada make personal jurisdiction even more important in the United States.

\section{B. Current Jurisdictional Rules do not Reflect How TNCs are Structured and Operate, Allowing TNCs that Violate International Human Rights Norms to Escape any Meaningful Accountability.}

Second, rules restricting assertions of personal jurisdiction over TNCs do not reflect how TNCs are structured and operate in today's world. Indeed, "a classic obstacle involving litigation against transnational businesses is that corporate groups are organized as a network of distinct legal entities." ${ }^{251}$ Not only are such entities extremely complex and often lack transparency regarding their structure, they are increasingly amorphous. In today's global world, related legal entities within a transnational business enterprise are frequently without clear definitions, and often exist without obvious "parent" entities whose domicile or place of incorporation can easily be determined by even the most sophisticated actors. In fact, many organizations addressing similar problems with TNCs are beginning to drop the term "parent company" altogether, using other terms such as "lead company," given this reality. ${ }^{252}$ Truth be told, most countries' legal systems are simply no match for these increasingly massive, complex, and amorphous legal structures.

BUNDESGERICHTS [BGE] III 153 (Switz.). In that case, GIRCA alleged that IBM had been complicit in the crimes against humanity the Nazis committed against the Roma between 1933 and 1945. The Federal Court (Tribunal Federal) recognized that the Swiss courts had jurisdiction to hear the case, but dismissed it after finding too much time had elapsed. Bundesgericht [BGer] [Federal Supreme Court] Aug. 14, 2006, 132 ENTSCHEIDUNGEN DES SCHWEIZERISCHEN BuNDESGERICHTS [BGE] III 661, 668 (Switz.). However, GIRCA is an important precedent for the filing of claims against companies operating in Switzerland which are alleged to have been involved in human rights violations extraterritorially.

246. Skinner, Beyond Kiobel, supra note 11, at 233.

247. Id. at $227-28$.

248. Id. at 231 .

249. Id. at 242 .

250. Id. at $245-47$.

251. Id. at 215. See also Kirshner, supra note 233, at 266-67 (noting how multinational corporations structure themselves to avoid a court's jurisdiction, and how they can shift financial assets within a corporate group).

252. See Gwynne L. Skinner, Notes of Discussion on Advancing Parent Company Accountability: A Roadmap for Policy and Legal Reform, from Int'l Corp. Accountability Roundtable, Washington, D.C. (Sept. 7, 2016) (notes on file with author). 
A description of the varied types of complex business structures employed by large, transnational businesses is outside the scope of this Article. However, a few key facts about corporate growth and structure are important to note, given the current jurisdictional paradigm's focus on the "home" (or in Europe, the domicile) of a corporation-a paradigm that is based on dated notions of how TNCs are structured.

Transnational business, including the number of "parent" (or lead) corporations and subsidiaries, has exploded over the last 40 years, with much of the expansion taking place in developing countries as those countries have sought to attract transnational business. ${ }^{253}$ In 1970, there were approximately 7,000 transnational corporations in the world; that number grew to 30,000 by 1990 , to 63,000 by 2000 , and to 82,000 by $2009{ }^{254}$ Today, there are more than 100,000 multinational corporations with over 900,000 foreign affiliates. ${ }^{255}$ Moreover, as companies grow in size and expand overseas, the number of subsidiaries tends to increase and companies'. structures become even more complex. ${ }^{256}$ For example, even as long ago as 1984, British Petroleum had numerous sub-holding companies and over 1,200 subsidiaries. ${ }^{257}$ One can visualize the immense complexity of corporate structures, including "parents," subsidiaries, affiliates, and "related entities" of numerous TNCs by referring to Bloomberg Law, Companies and Markets, and Corporate Hierarchies. ${ }^{258}$ The United Nations Conference on Trade and Development cannot even compile complete and accurate financial data on transnational corporations because of their complexity, their number

253. See Ramon Torrent \& Federico Lavopa, Strengthening Enforcement of Core Labour Rights: Can a New Investment Agreement Model Help Multinational Corporations Be More Socially Responsible?, in CORP. SOC. RESPONSIBILITY IN LATIN AM.: A COLlECTION OF RESEARCH PAPERS FROM THE UNCTAD VIRTUAL INST. NETWORK 101,105 (2010) (describing the major shift in "the will and the ability" of developing countries to control the activities of multinational corporations (MNCs), and the emphasis on attracting them over regulating them) (citing Jenkins, supra note 242, at 1).

254. U.N. Conference on Trade \& Development, World Investment Report 2009: Transnational Corporations, Agricultural Development and Production, xxi, U.N. Doc. UNCTAD/WIR/2009 (July 2009).

255. Damiano de Felice, Business and Human Rights Indicators to Measure the Corporate Responsibility to Respect: Challenges and Opportunities, 37 HUM. RTS. Q. $511,517(2015)$.

256. DeloitTe, Governance of Subsidiaries: A Survey of Global Companies 3 (2013), http://www2.deloitte.com/content/dam/Deloitte/in/Documents/risk/Corporate $\% 20$ Governance/in-gc-governance-of-subsidiaries-a-survey-of-global-companies-noexp.pdf.

257. Phillip I. Blumberg, Accountability of Multinational Corporations: The Barriers

Presented by Concepts of the Corporate Juridical Entity, 24 HASTINGS INT'L \& COMP. L. REV. 297, 303 (2001) [hereinafter Accountability of Multinational Corp.] (citing Hadden, Inside Corporate Groups, 12 INT'L J. SoC. L. 271, 274 (1984)).

258. BLOOMBERG LAW, https://www.bloomberglaw.com/ (last visited October 7, 2016). 
of categorizations of holding companies, and the fact that a subsidiary can be owned by multiple parent corporations. ${ }^{259}$

Over the last several decades, as TNCs have grown and created other corporations, they have rapidly changed form, with the emergence of complex multi-tiered corporate structures that include numerous affiliated entities that collectively conduct the business of the enterprise. ${ }^{260}$ Even the "complex" corporate structures described a decade ago by a well-known scholar as "multi-tiered multinational corporate group[s] function with a parent corporation, sub-holding companies, and scores or hundreds of subsidiary corporations organized under the laws of countries around the globe, ${ }^{, 261}$ no longer completely captures the changing structures and complexities of TNCs over the last couple of decades. This hierarchal, pyramid approach, with a parent company at the top and numerous subsidiaries - typically used by AngloAmerican and British companies ${ }^{262}$-although itself complex, is now dated and becoming quickly obsolete. ${ }^{263}$ Yet, as one well-known scholar of corporate structure notes, this is the typical model that judges and policy-makers had (and continue to have) in mind when thinking about regulation and legal doctrines pertaining to $\mathrm{TNCs}^{264}$

Although there have been numerous types of corporate structures, such as those based on geographic division, product division, functional division, international division, or a combination thereof with various

259. Transnational Corporations Statistics, U.N. Conf. ON TRADE \& DEV., http://unctad.org/en/Pages/DIAE/Transnational-Corporations-Statistics.aspx (last visited Oct. 10, 2015).

260. Phillip I. Blumberg, Limited Liability and Corporate Groups, 11 J. CoRP. L. 573, 604 (1986).

261. See Blumberg, Accountability of Multinational Corp., supra note 257, at 300, 303. See also. William D. Dexter, Attribution of a Multinational Corporation's Net Income: The Position of the Unitary States Regarding Combined Reporting, 18 VAND. J. TRANSNAT'L L. 311,314 (1985) (noting the complexity of the modern business structure, including (1) the size and international scope of business operations; (2) developments in business organization, operation and structure, such as conglomeration; (3) diversification; (4) use of affiliated corporations to hold property and/or to conduct business; (5) substantial income from investments in intangible assets; (6) treatment of each corporation, irrespective of control or ownership by another, as a distinct legal entity; (7) technological changes in the way businesses are being conducted; and (8) different kinds and levels of control exercised by a multinational corporation over its various operating divisions and/or affiliated corporations).

262. Peter T. MUChlinski, Multinational ENTERPrises \& the LaW 56 (2d ed. 2007).

263. Id.

264. Id. The Anglo-American "pyramid group" type of structure consists of a parent company which owns and controls a network of wholly or majority-owned subsidiaries, which may themselves be intermediate holding companies for sub-groups of closely held subsidiaries. The resulting structure is that of a "pyramid" with the parent company at its apex. As noted above, when the "pyramid" crosses borders, this represents the "classic" conception of the MNE which underlies much of the thinking on MNE regulation. Id. 
branches and subsidiaries, ${ }^{265}$ many multinational companies employ the "matrix division" structure, the "most complex" of the international organizational structures. ${ }^{266}$ In "matrix division," a company's reporting relationships are set up as a grid, or matrix, rather than in the traditional hierarchy. ${ }^{267}$ This more recent shift away from a hierarchical, vertical control structure has also been referred to as "heterarchical."268 This change has resulted in the blurring of corporate-entity boundaries. As one corporate-structure scholar has described,

The trend towards 'heterarchy' may lead firms to spread certain functions geographically across the enterprise ... the firm itself could be reorganized into smaller, self-standing units of decision-takers who will come together in a mix that fits the business tasks that the firm faces, without creating permanent organizational structures... the organizational boundaries between individual firms themselves will begin to blur, as increased numbers of strategic alliances are formed. ${ }^{269}$

Forbes has also noted this trend regarding business entities and their suppliers, noting that, "In the past, strict hierarchical control of suppliers was necessary. Yet MNCs now need to operate as integrators of a loosely coupled, autonomous and geographically dispersed system of production.,"270

With mergers, things are even more complex-often there is not one main "parent" company. With mergers involving European companies, often there is "the creation of a twin holding company located in each home state, based on joint shareholding by the founding parent companies, and the transfer of operating activities to subsidiaries that may be jointly or separately owned and controlled by the holding

265. Michigan State University's International Business Center has a simplified tutorial on organizational structures of multinational corporations. GlobalEDGE, Organizational Structure of MNCs, MiCH. STATE UNIV. INT'L BUS. CTR., https://globaledge.msu.edu/content/onlinecoursemodules/33/organizational-structure-ofmncs/player.html (last visited Sept. 2, 2016).

266. MUCHLINSKI, supra note 262, at 47.

267. Sarianna M. Lundan, The Coevolution of Transnational Corporations and Institutions, 18 IND. J. Global LeGAL STUD. 639 (2011). Many transnational corporations have recently employed the "M-Form" model, a structure that increases the number of "outside" suppliers a corporation uses. Id. at 640.

268. MUCHLINSKI, supra note 262 , at 46.

269. Id. at 48. This new approach to corporate organization has been followed in recent years by several leading MNEs, including BP, among others. Id.

270. Multinational Corporations Strive to Compete, ForBEs (Aug. 31, 2010, 6:00 AM), http://www.forbes.com/2010/08/30/multinational-corporation-economy-oecd-busin ess-oxford.html. 
companies."271 This was how Royal Dutch Shell was structured until 2005 . $^{272}$

Transnational financial institutions pose special complexities in their structure. ${ }^{273}$ Because there are stricter requirements for the subsidiaries of financial institutions, many banks either open a branch or satellite abroad, and many are transforming their subsidiaries into satellites, in order to avoid these stricter regulations. ${ }^{274}$ Branches can typically transfer capital and liquid assets across national borders with little regulation, and thus little transparency. ${ }^{275}$

Current jurisdictional paradigms based on a place of domicile or "home" simply do not match how TNCs are structured and operate today. Thus, expansion of personal jurisdiction over TNCs is both reasonable and fair.

\section{THE UNITED STATES SHOULd REQUIRE TNCS DOING BUSINESS IN THE UNITED STATES TO CONSENT TO GENERAL PERSONAL JURISDICTION FOR FEDERAL CAUSES OF ACTION.}

Given the complex corporate structure of transnational corporations, Daimler and Goodyear's limitation of a court's assertion of personal jurisdiction over a corporate defendant will limit victims' ability to hold transnational corporations accountable and obtain a remedy even where Congress has provided one because, in many cases, courts will not be able to assert personal jurisdiction over the corporate entity responsible for the harm. Such is true even though the responsible corporate entity has significant presence in the United States and engages in significant economic activity within the United States. In fact, transnational corporations with headquarters abroad do more business in the United States than in any other country in the world. ${ }^{276}$ Transnational businesses from the United Kingdom do the most business in the United States, followed by Japan, the Netherlands, Canada, Luxemburg, Germany, Switzerland, and France. ${ }^{277}$ Foreign-owned factories based in the United

271. MUCHLINSKI, supra note 262, at 59.

272. Id.

273. Tobias H. Tröger, Organizational Choices of Banks and the Effective Supervision of Transnational Financial institutions, 48 TEX. INT'L L.J. 177 (2012).

274. Id. at 181 .

275. Id. at $182,196$.

276. See ORG. FOR INT'L INV., FOREIGN DIRECT INV. IN THE UNITED STATES: 2016 REPORT 2 (2016), http://ofii.org/sites/default/files/Foreign\%20Direct\%20Investment $\% 20 \mathrm{in} \% 20$ the $\% 20$ United $\% 20$ States $\% 202016 \% 20$ Report.pdf (last accessed Sept. 2, 2016). This is true on a cumulative basis; it has been true every year except for 2014, when flows into China and Hong Kong exceeded the United States, primarily due to the disinvestment of Vodofone (U.K. business). Id. at 3.

277. Id. at 3 . 
States also export billions of dollars' worth of goods made in the United States; in 2008, such was nearly a fifth of all U.S. exports."278

\section{A. Congress Should Enact a Statute Requiring All TNCs that Do Business in the United States to Consent to Personal Jurisdiction Where Congress Has Provided a Claim for Extraterritorial Conduct.}

For all the reasons outlined above, this Article suggests that just as U.S. courts responded to changes in corporate structure and operations by expanding jurisdiction in the late 1800 s and early 1900 s, Congress should do the same now to account for analogous changes in TNCs and their operations. However, because Daimler and Goodyear are decisions based on the Constitution, Congress' actions are limited. For 'example, Congress cannot simply enact a statute providing that all corporations that do substantial and continuous business in the United States are subject to the personal jurisdiction of U.S. courts. Such would likely be considered unconstitutional legislation. Therefore, Congress will necessarily need to accomplish expanded personal jurisdiction by requiring the consent of TNCs doing business in the United States. ${ }^{279}$

Specifically, Congress should respond to Daimler and Goodyear by expanding jurisdiction, requiring any transnational businesses "doing business" in the United States to explicitly consent to general personal jurisdiction of U.S. courts where Congress has provided for a cause of action for extraterritorial conduct. Although Congress could then statutorily determine what constitutes "doing business," it should include conducting business through the existence of a U.S. subsidiaryessentially addressing the limitation set forth in Daimler. Although a full analysis is outside the scope of this Article, the European Union, European countries, and Canada should also similarly expand personal jurisdiction over transnational corporations. ${ }^{280}$ This is both because

278. See Deborah Orr, The Largest Foreign Investments in the U.S., FORBES (Apr. 10, 2008, 4:00 PM), http://www.forbes.com/2008/04/10/foreign-investment-stocks-2000glob al08-biz-cx_do_0410investments.html.

279. At least two scholars have recently recommended that individual states could and should take this course of action where the state has some interest, such as where the harm occurs in the state or the plaintiffs reside in the state. Cassandra Burke Robertson \& Charles W. "Rocky" Rhodes, A Shifting Equilibrium: Personal Jurisdiction, Transnational Litigation, and the Problem of Nonparties, 19 LewIS \& CLARK L. REV. 643, 661-66 (2015) [hereinafter Robertson \& Rhodes, A Shifting Equilibrium].

280. Specifically, the EU should revise its regulations regarding jurisdiction to ensure that it has jurisdiction over any entity that does substantial business in an EU state so that where causes of action for extraterritorial conduct exist, EU state courts have the ability to hear and adjudicate the claim. Similarly, European States should also ensure they have jurisdiction over transnational corporations that do significant business within them. 
doing so would create a more even playing field for each region's transnational business, and so that there becomes a true transnational personal jurisdiction over TNCs.

Although this Article proposes that Congress provide for general jurisdiction only for federal claims, it might be feasible to require such consent in cases in federal court involving diversity jurisdiction whenever a cause of action exists for extraterritorial conduct, even if provided for by the states. This would also address some of the limitations in specific personal jurisdiction set forth in Nicastro. However, to the degree that the Fifth Amendment applies to federal courts' assertions of personal jurisdiction when the claim involves a federal cause of action rather than the Fourteenth Amendment, personal jurisdiction only for federal claims may best withstand scrutiny. ${ }^{281}$

It remains undecided whether individual states can constitutionally require corporations doing business within it to consent to general personal jurisdiction through registering their business in the state and appointing an agent. ${ }^{282}$ Before Daimler, several courts found that registration to do business and appointment of an agent constituted consent for specific personal jurisdiction. ${ }^{283}$ However, numerous courts

Canada has more expansive jurisdiction than the United States does now post-Daimler. See generally supra note 24 (discussing jurisdiction in Canada). However, Canada should expand even this more expansive jurisdiction to ensure that it has claims over transnational corporations doing business in Canada, so that where Canada has provided causes of action that include extraterritorial actions, Canadian courts can adjudicate the claims.

281. See, e.g., Simowitz, supra note 10, at 6 (noting arguments that Fifth Amendment applies to federal court's assertion of general personal jurisdiction, which is arguably less restrictive). However, given that the Federal Rules of Civil Procedure base even federal courts' jurisdiction on whether the state court would have jurisdiction, it may well be, however, that the Fourteenth Amendment applies regardless. See FED. R. CIV. P. (4)(k).

282. See, e.g., Tanya J. Monestie, Registration Statutes, General Jurisdiction, and the Fallacy of Consent, 36 CARDOzo L. REV. 1343 (2015) (questioning the constitutionality of state registration statutes as implied consent to general personal jurisdiction in light of Goodyear and Daimler); see also Robertson \& Rhodes, A Shifting Equilibrium, supra note 279 , at 649,673 (questioning whether states provide for general personal jurisdiction); Brown v. Lockheed Martin Corp., 814 F.3d 619, 637 (2d Cir. 2016) ("[T]he analysis that now governs general jurisdiction over foreign corporations ... suggests that federal due process rights likely constrain an interpretation that transforms a run-of-themill registration and appointment statute into a corporate 'consent'-perhaps unwittingto the exercise of general jurisdiction by state courts ...."). But see Acorda Therapeutics Inc. v. Mylan Pharms. Inc., 817 F.3d 755, 767-68 (Fed. Cir. 2016) (noting that "International Shoe and Daimler did not overrule th[e] historic and oft-affirmed line of binding precedent" that "the appointment of an agent by a foreign corporation for service of process could subject it to general personal jurisdiction") (O'Malley, J., concurring), cert. denied sub nom. Mylan Pharms. v. Acorda Therapeutics, $137 \mathrm{~S}$. Ct. 625 (2017).

283. See Monestie, supra note 282, at 1369 (citing Holloway v. Wright \& Morrissey, Inc., 739 F.2d 695, 696-99 (1st Cir. 1984); Grey Line Tours v. Reynolds Elec. \& Eng'g Co., 238 Cal. Rptr. 419, 421-22 (Cal. Ct. App. 1987); Staley-Wynne Oil Corp. v. Loring 
also found that consent to general personal jurisdiction by way of registration and appointment of an agent for service was constitutional, ${ }^{284}$ with the circuit courts split on the issue. ${ }^{285}$ Moreover, several courts

Oil Co., 162 So. 756, 757-59 (La. 1935); Springle v. Cottrell Eng'g Corp., 391 A.2d 456, 459-69 (Md. Ct. Spec. App. 1978); Mittelstadt v. Rouzer, 328 N.W.2d 467, 469-70 (Neb. 1982); Osage Oil \& Ref. Co. v. Interstate Pipe Co., 253 P. 66, 69 (Okla. 1926); Eure v. Morgan Jones \& Co., 79 S.E.2d 862, 863-68 (Va. 1954)).

284. See Monestie, supra note 282 at 1359, 1369 (citing Bane v. Netlink, Inc., 925 F.2d 637, 640-41 (3d Cir. 1991); Knowlton v. Allied Van Lines, Inc., 900 F.2d 1196, 1199-2000 (8th Cir. 1990); Bohreer v. Erie Ins. Exch., 165 P.3d 186, 191-94 (Ariz. Ct. App. 2007); Sternberg v. O’Neil, 550 A.2d 1105, 1109-16 (Del. 1988); Confederation of Can. Life Ins. Co. v. Vega y Arminan, 144 So. 2d 805, 808-10 (Fla. 1962); Allstate Ins. Co. v. Klein, 422 S.E.2d 863, 864-65 (Ga. 1992); Merriman v. Crompton Corp., 146 P.3d 162,170-77 (Kan. 2006); Rykoff-Sexton, Inc. v. Am. Appraisal Assoc., 469 N.W.2d 88, 89-91 (Minn. 1991); Read v. Sonat Offshore Drilling, Inc., 515 So. 2d 1229, 1230-31 (Miss. 1987); Allied-Signal Inc. v. Purex Indus., Inc., 576 A.2d 942, 943-45 (N.J. Super. Ct. App. Div. 1990); Werner v. Prins, 861 P.2d 271, 272-74 (Ariz. Ct. App. 1991); Augsbury Corp. v. Petrokey Corp., 470 N.Y.S.2d 787, 789 (N.Y. App. Div. 1983); Simmers v. Am. Cyanamid Corp., 576 A.2d 376, 382 (Pa. Super. Ct. 1990); Green Mountain Coll. v. Levine, 139 A.2d 822, 824-25 (Vt. 1958)). As Professor Monestie points out, "courts differ on whether it is the act of registering to do business or the act of appointing an agent for service of process that constitutes consent to personal jurisdiction." See id. at 1359 n.86 (citing Sadler v. Hallsmith SYSCO. Food Servs., No. 08-4423 (RBK/JS), 2009 WL 1096309, at *2 (D.N.J. Apr. 21, 2009) ("Finally, the Court finds that even if, as Defendants maintain, Plaintiffs did not serve Hallsmith's registered agent in New Jersey, the Court would still have jurisdiction. While the language of Allied Signal suggests that the act of serving a corporation's registered agent confers jurisdiction on the courts of a state, the Third Circuit Court of Appeals has instead stated that the act of registering to do business constitutes consent to be sued.") (internal citations omitted)).

285. Before Daimler, circuit courts were split as to whether compliance with business registration or agent designation statutes subjected a defendant to personal jurisdiction. See Forest Labs., Inc. v. Amneal Pharms. L.L.C., No. 14-508LPS, 2015 WL 880599, at *9 (D. Del. Feb. 26, 2015). See also Kevin D. Benish, Pennoyer's Ghost: Consent, Registration Statutes, and General Jurisdiction After Daimler AG v. Bauman, 90 N.Y.U. L. Rev. 1609, 1611-13 (2015) (citing the Third and Eighth Circuits' holding that consent-by-registration is constitutional; citing the Second and Ninth Circuits' support for the Third and Eighth Circuits in dicta; citing the First, Fourth, Fifth, Seventh, and Eleventh Circuits' holding that consent-by-registration is unconstitutional; citing that the Sixth, Tenth, D.C., and Federal Circuit Courts of Appeal have yet to take a position); Rhodes \& Robertson, Toward a New Equilibrium in Personal Jurisdiction, supra note 23, at 229. For cases that held compliance with registration statutes could amount to valid consent to personal jurisdiction, see Holloway v. Wright \& Morrissey; Inc., 739 F.2d 695, 697 (1st Cir. 1984); Spiegel v. Schulmann, 604 F.3d 72 (2d Cir. 2010) (dicta); Bane v. Netlink, Inc., 925 F.2d 637, 640 (3d Cir. 1991); Knowlton v. Allied Van Lines Inc., 900 F.2d 1196, 1199-1200 (8th Cir. 1990); King v. Am. Family Mut. Ins. Co., 632 F.3d 570 (9th Cir. 2011) (dicta). For cases that held that compliance with a state registration statute cannot be the basis for finding consent to general jurisdiction, see Cossaboon v. Me. Med. Ctr., 600 F.3d 25, 37 (1st Cir. 2010); Ratliff v. Cooper Labs. Inc., 444 F.2d 745, 748 (4th Cir. 1971); Siemer v. Learjet Acquisition Corp., 966 F.2d 179 (5th Cir. 1992); Wilson v. Humphreys (Cayman) Ltd., 916 F.2d 1239, 1245 (7th Cir. 1990); Consol. Dev. Corp. v. Sherritt, Inc., 216 F.3d 1286, 1293 (11th Cir. 2000). 
found that registering to do business and appointing an agent did not create a separate jurisdictional basis, but is only a procedural mechanism for ensuring service of process. ${ }^{286}$ At least one jurisdiction, the District of Columbia, has a statute that explicitly states that the registration of an agent for service does not create a mechanism for personal jurisdiction. $^{287}$

Since Daimler, courts have remained split on the issue, but the only circuit court since Daimler to consider the issue rejected the notion of state-based consent to jurisdiction through registration and designating a registered agent. $^{288}$ In its decision, however, the Second Circuit held

286. Monestie, supra note 282, at 1369 (citing Consol. Dev. Corp. v. Sherritt, Inc., 216 F.3d 1286, 1293 (11th Cir. 2000); Wenche Siemer v. Learjet Acquisition Corp., 966 F.2d 179, 180-84 (5th Cir. 1992); Leonard v. USA Petrol. Corp., 829 F. Supp. 882, 88889 (S.D. Tex. 1993); In re Mid-Atl. Toyota Antitrust Litig., 525 F. Supp. 1265, 1277-78 (D. Md. 1981), aff'd, 704 F.2d 125 (4th Cir. 1983); Freeman v. Second Jud. Dist. Court ex rel. Cty. of Washoe, 1 P.3d 963, 965-68 (Nev. 2000); Byham v. Nat'l Cibo House Corp., 143 S.E.2d 225, 231 (N.C. 1965); Wash. Equip. Mfg. Co., Inc. v. Concrete Placing Co., Inc., 931 P.2d 170, 172-73 (Wash. Ct. App. 1997)).

287. D.C. CODE $§ 29-104.14$ (2011) ("The designation or maintenance in the District of a registered agent shall not by itself create the basis for personal jurisdiction over the represented entity in the District.").

288. Brown v. Lockheed Martin Corp., 814 F.3d 619, 626 (2d Cir. 2016) ("[U]pon our examination of the applicable Connecticut law, we conclude that by registering to transact business and appointing an agent under the Connecticut statutes-which do not speak clearly on this point-Lockheed did not consent to the state courts' exercise of general jurisdiction over it. A more sweeping interpretation would raise constitutional concerns prudently avoided absent a clearer statement by the state legislature or the Connecticut Supreme Court."). The court in Brown also noted that a "carefully drawn state statute that expressly required consent to general jurisdiction as a condition on a foreign corporation's doing business in the state, at least in cases brought by state residents, might well be constitutional," essentially overturning Vera v. Republic of Cuba, 91 F. Supp. 3d 561, 566-67, 571 (S.D.N.Y. 2015) (holding that the defendant corporation consented to jurisdiction for purposes of responding to subpoenas through registering to do business). Id. at 641 .

For other post-Daimler cases finding that consent by registration is not valid, see, for example, Leibovitch v. Islamic Republic of Iran, 188 F. Supp. 3d 734, 750 (N.D. Ill. 2016) (noting that other district courts in the 7th Circuit have similarly held); Display Works, $L L C$ v. Bartley, 182 F. Supp. 3d 166, 176 (D.N.J. 2016) (finding that a Wisconsin corporation did not consent to general jurisdiction of New Jersey by registering to do business and appointing an agent, both because the statute did not expressly state the company was subjecting itself to jurisdiction, and because more recent, contact-based jurisprudence has called into question the consent by registration theory); Lanham $v$. Pilot Travel Ctrs., No. 03:14-CV-01923-HZ, 2015 WL 5167268, at *11 (D. Or. Sept. 2, 2015) (finding that registration pursuant to Oregon's foreign business registration statute did not provide a basis for consent to jurisdiction, given that the statute did not mention jurisdiction); Keeley v. Pfizer, Inc., No. 415-CV-00583 ERW, 2015 WL 3999488, at *4 (E.D. Mo. July 1, 2015) (rejecting consent to jurisdiction simply because a company was registered with Missouri and required to appoint an agent for service of process); AstraZeneca $A B$ v. Mylan Pharms., Inc., 72 F. Supp. 3d 549, 556 (D. Del. 2014) ("In light of the holding in Daimler, the court finds that Mylan's compliance with Delaware's registration statutes-mandatory for doing business within the state-cannot constitute 
open the possibility that "a carefully drawn state statute" that expressly required consent to general jurisdiction in exchange for a foreign corporation's doing business in the state, at least in cases brought by state residents, might well be constitutional. ${ }^{289}$

In fact, Pennsylvania has a statute-and it appears to be the only state with such a statute - that specifically provides in its long-arm statute for general personal jurisdiction over a foreign corporation that has received "qualification as a foreign corporation" under the state registration statute. ${ }^{290}$ The courts in Pennsylvania have applied the statute according to its language. ${ }^{291}$ Although it has not been interpreted since Daimler, it might fit into the type of statute contemplated in Brown.

consent to jurisdiction, and the Delaware Supreme Court's decision in Sternberg [ $v$. O'Neil, 550 A.2d 1105, 1116 (Del. 1988) (holding that compliance with registration statutes creates personal jurisdiction)] can no longer be said to comport with federal due process."), aff'd on different grounds, Acorda Theurapeutics, Inc. v. Mylan Pharms. Inc., 817 F.3d 755 (Fed. Cir. 2016), (finding specific jurisdiction); Fiduciary Network, L.L.C. v. Buehler, No. 3:15-CV-0808, 2015 WL 2165953 (N.D. Tex. May 8, 2015).

For cases finding registration constitutes consent, see, for example, Mitchell v. Eli Lilly and Co., 159 F. Supp. 3d 967, 977-79 (E.D. Mo. 2016) (finding Missouri's business registration statute and requirement of agent for service of process equated to consent for general personal jurisdiction, and stating that neither Daimler nor Goodyear addressed consent as a separate basis); Acorda Theurapeutics, 78 F. Supp. 3d at 588 ("Daimler does not eliminate consent as a basis for a state to establish general jurisdiction over a corporation which has appointed an agent for service of process in that state, as is required as part of registering to do business in that state, noting that Daimler did not address consent"), aff'd on different grounds, 817 F.3d 755 (Fed. Cir. 2016) (affirming the district court's finding of specific jurisdiction); Otsuka Pharm. Co., Ltd. v. Mylan Inc., 106 F. Supp. 3d 456, 468 (D.N.J. 2015) (finding registration under New Jersey business statute constituted consent to be sued, even in light of Daimler, and noting that Daimler suggests consent is a separate basis of jurisdiction); Forest Labs., 2015 WL 880599 , at *10 (finding Daimler did not affect rule that registering to do business constituted consent to personal jurisdiction, and that the Delaware Supreme Court decision in Sternberg v. O'Neil is still good law).

289. See Brown, 814 F.3d at 626. Similarly, another federal case suggests that a state could theoretically have a corporation's consent to jurisdiction if due process was satisfied, but also finding that simply registering and naming an agent does not satisfy due process. See Keeley, 2015 WL 3999488 , at *4.

290. 42 PA. Cons. STAT. $\S 5301$ (a)(2)(i)-(ii) (2016).

291. See Eagle Traffic Control, Inc. v. James Julian, Inc., 933 F. Supp. 1251, 1256 (E.D. Pa. 1996).

[Plaintiff] bases general personal jurisdiction over [the defendant] on the ground that it is qualified to do business within this state as a foreign corporation. Pennsylvania's personal jurisdiction statute expressly grants jurisdiction in such an instance... . The bottom line is that Pennsylvania's long arm statute provides for personal jurisdiction when a foreign corporation takes the particular action of becoming authorized to do business in Pennsylvania.

Id. 
In addition to the fact that it may be most efficient for Congress to enact such a statute rather than individual states, a federal statute might also survive constitutional challenges that state legislation might not, especially where the foreign corporations are domiciled outside of the United States. ${ }^{292}$ For example, some might argue that allowing states to legislate and potentially impede commerce with corporations domiciled abroad may be unconstitutional under the Dormant Commerce Clause. ${ }^{293}$ As noted earlier, the Supreme Court in 1910 found that it was a violation of the Commerce Clause for a state to impose limitations on foreign corporations doing business within the state, and that only Congress could do so. ${ }^{294}$

Even if such is not prohibited under the Dormant Commerce Clause, some might challenge state laws requiring consent due to other federal-related concerns. One example is implied federal preemption. ${ }^{295}$ Although states primarily regulate business, whether domestic or foreign, Congress has increasingly "occupied the field"296 when it comes to

292. I take no personal view on whether states can constitutionally enact their own consent statutes for TNCs doing business in the states, and a full analysis of the constitutionality of such state action is outside the scope of this article. The point I am trying to make is that a federal statute would not be as vulnerable to constitutional challenges.

293. The Dormant Commerce Clause does not expressly exist in the text of the United States Constitution. It is, rather, a doctrine deduced by the U.S. Supreme Court and lower courts from the actual Commerce Clause of the Constitution, which provides Congress with the authority to regulate commerce with foreign nations and "the several states." U.S. CoNST. art. I, $\S 8$, cl. 3. See also Or. Waste Sys., Inc. v. Dep't of Envtl. Quality, 511 U.S. 93, 98 (1994) ("[T]he Clause has long been understood to have a 'negative' aspect that denies the States the power unjustifiably to discriminate against or burden the interstate flow of articles of commerce.") (citing Wyoming v. Oklahoma, 502 U.S. 437, 454 (1992); Welton v. Missouri, 91 U.S. 275 (1876)). Some scholars question whether the Dormant Commerce Clause actually exists as a prohibition on state action. See, e.g., Tim A. Lemper, The Promise and Perils of "Privileges or Immunities": Saenz v. Roe, 119 S. Ct. 1518 (1999), 23 HARV. J. L. \& PuB. PolicY 295, 309 (1999) (noting critiques by Supreme Court Justices of the Dormant Commerce Clause as an "over-broad and illegitimate constraint on state power"); S. Mohsin Reza, DaimlerChrysler v. Cuno: An Escape from the Dormant Commerce Clause Quagmire?, 40 U. RICH. L. REV. 1229, 1251 (2006) (discussing Justice Thomas' and Justice Scalia's criticisms of the Dormant Commerce Clause); Norman R. Williams, Why Congress May Not "Overrule" the Dormant Commerce Clause, 53 UCLA L. REV. 153, 163 (2005).

294. See Int'l Textbook Co. v. Pigg, 217 U.S. 91, 108-09 (1910); see also supra note 45. Interestingly, none of the cases discussed above cite to that case. It is unclear why.

295. Preemption is the "principle (derived from the Supremacy Clause) that a federal law can supersede or supplant any inconsistent state law or regulation." Preemption, BLACK's LAW DICTIONARY (10th ed. 2014). Implied preemption is determined by "inquiring whether Congress has occupied a particular field with the intent to supplant state law or whether state law actually conflicts with federal law." Cipollone v. Liggett Grp., Inc., 505 U.S. 504, 532 (1992).

296. Field preemption is a form of implied preemption where the federal government indicates it intends to occupy a specific regulatory field, and thus any conflicting state 
interstate and foreign commerce. ${ }^{297}$ Moreover, some courts might strike down state consent statutes under the foreign affairs doctrine, ${ }^{298}$ with courts ultimately finding that only Congress can impose conditions requiring a non-U.S based corporation to consent to general personal jurisdiction in exchange for doing business.

Regardless of whether individual states may or may not be able to constitutionally require such consent as a condition for doing business due to the commerce clause or foreign preemption, there is no constitutional rule that prevents the federal government from requiring such consent. $^{299}$ In fact, the Commerce Clause expressly allows this. The Commerce Clause clearly gives Congress the power to "Regulate Commerce with foreign Nations." $" 300$ Additionally, having Congress enact such a statute would not raise the same issues related to federal preemption and the foreign affairs doctrine that are raised when a state enacts such laws. Moreover, limiting general jurisdiction to federal causes of action would allow courts to rest more assured that Congress and the executive branch have considered foreign policy implications.

A federal statute could simply state that all businesses domiciled abroad that are "doing business" in the United States need to register with each state where it does business, provide an agent for service (which they typically already have to do), ${ }^{301}$ and explicitly provide that, by doing so, the foreign corporation is consenting to general personal jurisdiction for any federal claims that provide for extraterritorial

law could be struck down. See Pennsylvania v. Nelson, 350 U.S. 497, 509 (1956). See also Gade v. Nat'l Solid Wastes Mgmt. Ass'n, 505 U.S. 88, 108 (1992) ("[U]nder the Supremacy Clause, from which our pre-emption doctrine is derived, " "any state law, however clearly within a State's acknowledged power, which interferes with or is contrary to federal law, must yield."'") (quoting Felder v. Casey, 487 U.S. 131, 138 (1988) (quoting Free v. Bland, 369 U.S. 663, 666 (1962))).

297. See, e.g., Sherman Antitrust Act, 15 U.S.C. $\S \S 1-7$ (2012); Copyright Act of 1976, 17 U.S.C. $\S \S 101-810$ (2012); Labor Management Relations (Taft-Hartley) Act, 29 U.S.C. $\S \S 141-531$ (2012); Wickard v. Filburn, 317 U.S. 111, 124 (1942) (holding that Congress can regulate any commercial activity that has an effect on interstate trade).

298. Under the foreign affairs doctrine, state laws that could affect foreign affairs are invalid because the power to manage foreign affairs is reserved by the federal government. See Zschernig v. Miller, 389 U.S. 429, 432 (1968).

299. See generally Benish, supra note 285.

300. U.S. CONST. art. I, $\S 8$, cl. 3.

301. All businesses, including foreign, domestic, incorporated, and unincorporated, typically have to register with each state in which they do business and establish a registered agent, regardless of whether the business is incorporated in that state. See Caron Beesley, Selling into the U.S. as a Foreign Business: Should You Incorporate Your Business Here?, SMALl Bus. Assoc.: STARTING A BusINEss (last updated Aug. 18, 2015), https://www.sba.gov/blogs/selling-us-foreign-business-should-you-incorporateyour-business-here. It seems that only foreign businesses which sell exclusively online or through a U.S. wholesaler are exempt from the general requirement for business registration. Id. 
application. ${ }^{302}$ Such explicit language would provide fair notice to foreign corporations that they are subject to the general jurisdiction of U.S. courts where a cause of action exists, alleviating due process concerns.

Some might question whether requiring consent is true consent, leading to Constitutional Due Process concerns. One scholar has given a very in-depth analysis and remains very skeptical about whether states can require foreign corporations to consent to jurisdiction through registration statutes, noting that consent through registration has none of the hallmarks of actual consent, raising issues of fundamental fairness. ${ }^{303}$ Although coerced consent would remain an issue under the proposed statute, a federal statute raises fewer concerns in this regard. This is because foreign corporations do not have any constitutional rights before they are haled into a U.S. court. ${ }^{304}$ Therefore, they do not have due process rights in the same way a U.S. business has due process rights. Moreover, coerced consent concerns have been raised in the context of businesses within one U.S. state having to consent to the jurisdiction of another U.S. state, not a TNC seeking permission to do business in the United States. ${ }^{305}$ To the degree there are resulting concerns about whether the proposed statute would "chill" TNCs from doing business in the United States, such is unlikely. This is because TNCs stand to gain enormously from doing business in the United States, and ultimately, the types of suits that could be brought are few, and limited only to those "bad apples" that violate human rights.

A federal statute has the additional benefit of satisfying Fed. R. Civ. P. $4(k)(1)(C)$, which provides that the service of summons establishes personal jurisdiction over the defendant when "authorized by a federal statute. ${ }^{.306}$ The statute should also indicate that for a claim arising under federal law, Fed. R. Civ. P. 4(k)(2) applies if the foreign corporation is doing business equally throughout the United States, allowing any federal court to assert jurisdiction over any corporation domiciled abroad

302. Alternatively, Congress could enact a statute allowing states to enact their own statutes to require foreign corporations doing business within the state to consent to general personal jurisdiction. For example, Congress has previously authorized state actions that might otherwise have been deemed preempted. See, e.g., Sudan Accountability and Divestment Act (SADA) of 2007, Pub. L. No. 110-174, 21 Stat. 2516 (2007) (authorizing states to divest from companies that conduct business operations in Sudan). For a discussion of the constitutionality of the SADA and similar legislation, see Perry S. Bechky, Darfur, Divestment, and Dialogue, 30 U. PA. J. INT'L L. 823 (2009). For the reasons discussed herein, however, I believe a federal statute is more efficient, more consistent, and more likely to satisfy due process and other constitutional concerns.

303. Monestie, supra note 282, at 1380-90, 1398.

304. See Simowitz, supra note 10, at 31-32.

305. Monestie, supra note 282, at 1380-90, 1398.

306. FED. R. CIV. P. 4(k)(1)(C). 
in such circumstances. ${ }^{307}$ It is important to note that although the Supreme Court has not decided the issue, lower circuit courts have held that it is constitutional to aggregate contacts for purposes of personal jurisdiction against a foreign defendant pursuant to the Fifth Amendment. $^{308}$ Thus, if the Fifth Amendment's Due Process Clause applies to foreign defendants in federal causes of action rather than the Fourteenth's Due Process Clause, asserting jurisdiction only for federal claims may best withstand scrutiny. ${ }^{309}$

\section{What Constitutes "Doing Business?"}

There is no specific definition for what constitutes "doing business," and courts typically determine "doing business" on a case-bycase basis. ${ }^{310}$ Congress could continue to allow individual states or courts to determine what "doing business" means, but that might raise due process concerns. Alternatively, Congress could provide a definition for "doing business." Congress could define "doing business" for purposes of the statute in a myriad of ways, setting forth a minimum monetary amount for transactions, trade, or sales, or the establishment of one or more offices, whether directly or through a subsidiary. But

307. In relevant part, the rule reads:

(2) Federal Claim Outside State-Court Jurisdiction. For a claim that arises under federal law, serving a summons or filing a waiver of service establishes personal jurisdiction over a defendant if:

(A) the defendant is not subject to jurisdiction in any state's courts of general jurisdiction; and

(B) exercising jurisdiction is consistent with the United States Constitution and laws.

FED. R. CIV. P. 4(k)(2).

308. See, e.g., Sec. Inv. Prot. Corp. v. Vigman, 764 F.2d 1309, 1315 (9th Cir. 1985) (noting that where a federal court has federal question jurisdiction over a case, as opposed to diversity jurisdiction, the court's personal jurisdiction over a defendant is not limited to the forum state's personal jurisdiction over the defendant; rather, the Fifth Amendment allows for nationwide personal jurisdiction over a defendant who has sufficient nationwide contacts) (citing Johnson Creative Arts v. Wool Masters, Inc., 743 F.2d 947, 950 (1st Cir. 1984) ("“[M]inimum contacts' with a particular district or state for purposes of personal jurisdiction is not a limitation imposed on the federal courts in a federal question case by due process concerns. The Constitution does not require the federal districts to follow state boundaries.")). See also Daetwyler Corp. v. R. Meyer, 762 F.2d 290, 293-95 (3d Cir. 1985).

309. See, e.g., Simowitz, supra note 10, at 6, 32 (noting arguments that the Fifth Amendment applies to federal courts' assertion of general personal jurisdiction, which is arguably less restrictive).

310. WOlters KluWer, Specific "DoIng Business ACtivities" that AfFect tHe FOREIGN QUALIFICATION REQUIREMENT 8 (2012), https://ct.wolterskluwer.com/sites /default/files/CT_Corporation_What_Constitutes_DBA_Foreign-

Qualification_WhitePaper_0.pdf. 
Congress should be sure to include that doing business means conducting such business through a subsidiary or similar entity.

\section{Expanded Jurisdiction is Not Unprecedented}

Such expansive personal jurisdiction is not unprecedented. Congress has pending legislation, the Foreign Manufacturers Legal Accountability Act (FMLAA), which attempts to do something similar to what is being recommended here: requiring foreign manufacturers that do business in the United States to register to do business, appoint an agent, and consent to the personal jurisdiction of U.S. courts. ${ }^{311}$

In addition, the Institute of International Law, a well-respected and Nobel-prize winning international legal organization, has suggested similarly expansive jurisdiction. It enacted a resolution on August 30, 2015, which provides for universal civil jurisdiction over defendants, either where no other State has a stronger connection with the claim, or "even though one or more other States have such stronger connections, such victims do not have available remedies in the courts of any other such State. $" 312$

Of course, it should be noted that such expanded jurisdiction is not quite as expansive as it sounds because there are a limited number of claims that include extraterritorial conduct. ${ }^{313}$. Moreover, courts would still have the doctrine of forum non conveniens ${ }^{314}$ available to dismiss those cases where, even though the harm occurred abroad, courts have good reason to believe are better litigated in a more convenient forum other than the United States.

311. Foreign Manufacturers Legal Accountability Act (FMLAA) of 2015, H.R. 3304, 114th Cong. (2015). For a discussion of this bill, see Press Release, Am. Assoc. for Just., AAJ Applauds Introduction of Foreign Manufacturers Legal Accountability Act (July 29, 2015). The FMLAA, if enacted, would require foreign manufactures that do business in the United States (through importation of goods) to register their business, appoint an agent, and consent to the jurisdiction of U.S. courts; similar legislation would require all businesses that do business in the United States register and consent to personal jurisdiction. $I d$.

312. Inst. of Int'1 L., 1 Res. En., Universal Civil Jurisdiction with Regard to Reparation for International Crimes (Aug. 30, 2015), http://www.andreasbucherlaw.ch/images/stories/res_iil_en_universal_civil_jurisdiction.pdf.

313. See Alien Tort Statute, $\overline{2} 8$ U.S.C. $\bar{\S} 1350$ (2012); Anti-Terrorism Act, 18 U.S.C. $\S \S 2332-33$ (2012); Trafficking Victims Protection Act, 18 U.S.C. $\S 1595$ (2012). See supra Part II.A for a discussion of the ATS.

314. This doctrine allows courts to dismiss a case, even where it can assert jurisdiction, on the basis that another jurisdiction is ostensibly more "convenient" for the parties and witnesses. See Gulf Oil Corp. v. Gilbert, 330 U.S. 501, 506-08 (1947). 


\section{B. A Statutory Enactment Would Provide for an Even Playing Field for U.S. Corporations.}

Allowing for personal jurisdiction over foreign corporations that conduct substantial and continuous business in the United States could actually be good for U.S. corporations, because it would create an even playing field for U.S. corporations. Under current personal jurisdiction rules, only those corporations incorporated or headquartered in the United States can be sued under the ATS, ATA, and the TVPA. Yet, transnational corporations that also conduct business in the United States and gain enormous benefit from operating in the United States-some perhaps that do more business than U.S.-based corporations-now no longer have to worry about being sued under these same statutes because U.S. courts cannot assert personal jurisdiction over them for the same violations. This means that foreign corporations not only have less exposure from lawsuits but will have to expend less and invest less money in human rights compliance than U.S. corporations. This puts those foreign corporations that otherwise do business in the United States at a competitive edge.

Finally, Justice Ginsburg argued for narrow jurisdiction partly because such narrow jurisdiction would provide certainty and clarity, which she felt was important out of fairness to foreign corporations. ${ }^{315}$ Providing for broad general personal jurisdiction where a transnational corporation does business provides the same level of certainty and clarity.

\section{Comity and Foreign Relations are not Substantial Impediments.}

Justice Ginsburg, in her Daimler opinion, argues that broad personal jurisdiction poses comity and foreign relations concerns as one justification for limiting general personal jurisdiction. ${ }^{316}$ There should be little question that it would be best for the United States, Canada, and Europe to move toward equally broad general personal jurisdiction over TNCs in order to ensure remedies for individual victims, for consistency in the enforcement of judgments, and to allay U.S. lawmakers' and judges' concerns of comity and foreign relations. However, even if the United States took this approach on its own, concerns of comity and foreign relations, although important, should not be substantial impediments. This is especially the case because the expansive personal jurisdiction this article advocates would only apply in those situations

315. Daimler AG v. Bauman, 134 S. Ct. 746, 760 (2014).

316. Id. at 763 . 
where Congress has provided for causes of action, ostensibly after taking foreign relations into consideration.

First, it is important to address the Restatement (Third) of The Foreign Relations Law of the United States' (Restatement) view on what this article has deemed "personal jurisdiction" but what the Restatement calls "adjudicative jurisdiction,",317 given its recognition as an informative legal treatise on international law. Arguably, the Restatement's authoritative view on the subject should provide assurance to Congress and policymakers that what this article is proposing is within the bounds of what the Restatement recognizes as authoritative international law on the subject, and ease comity and foreign relations concerns to a large extent.

The Restatement allows assertions of adjudicative (personal) jurisdiction and considers such reasonable both where, inter alia, the defendant consents to such jurisdiction and where the defendant "regularly carries on business." "318 The greater restrictions, from a comity perspective, arguably involve causes of action for extraterritorial conduct, or what the Restatement terms "jurisdiction to prescribe."319 However, the Restatement allows lawmakers to enact causes of action for extraterritorial conduct where actions are directed against the nation's security ${ }^{320}$ or are in the interests of its citizens. ${ }^{321}$ Importantly, the Restatement allows for prescriptive jurisdiction for those offenses that are recognized as of universal concern, such as violations of customary international law. ${ }^{322}$ Moreover, such prescriptions are not limited to criminal law, but allows for civil actions that provide a remedy or restitution for these offenses. ${ }^{323}$ Thus, providing for general personal jurisdiction over those TNCs consenting to general personal jurisdiction for the privilege of doing business in the United States for claims of extraterritorial violations of international law - such as international human rights violations, terrorism, and human trafficking (among potential others) - does not violate international law and is seen as a

317. Restatement (ThiRd) Of THE Foreign Relations LaW of THE United States \& 421 (AM. LAW INST. 1987).

318. Id. at $\S \S 421(2)(\mathrm{g})-(\mathrm{h})$. (discussing whether the person has consented to jurisdictional exercise and "regularly carries on business in the state").

319. Id. at $\S \S 402-04$.

320. Id. at $\$ 402(3)$.

321. Id. at $\S \S 402(2)-(3)$. However, such an action must be reasonable. Id. at $\S 403$. Although "reasonableness" takes into consideration a variety of factors, including whether another nation has an interest in regulating the conduct and the likelihood of conflict with another nation, id. at $\S 403(2)$, this reasonableness standard also allows lawmakers to consider legal and economic systems and the degree to which the desirability of such recognition is generally accepted. Id. at $\S \S 403(2)$ (c), (e).

322. Id. at $\S 404$.

323. Id. at ct. (b). 
proper exercise ' of authority. Moreover, given that Congress has provided for claims involving extraterritorial conduct, one can argue that Congress (and the executive through the signing of such bills) has taken potential conflicts with other nations into account before enacting such legislation.

Second, as discussed above in Part IV.A., EU countries protect their own corporations from expansive jurisdiction by other EU countries, but do not protect corporations that are domiciled outside an EU country (such as in the United States) from expansive jurisdiction. ${ }^{324}$ Thus, transnational corporations domiciled in the United States are subjected to actually fairly broad jurisdiction in numerous European countries. ${ }^{325}$ They are similarly exposed to broader jurisdictional rules in Canada. ${ }^{326}$ Thus, U.S. courts' assertion of jurisdiction over EU-domiciled transnational corporations should not pose comity problems with nations in Europe or Canada.

Third, the United States has allowed foreign corporations without headquarters in the United States to be sued in U.S. courts for decades without serious foreign policy repercussions. Moreover, if comity was a major concern, one would think that Congress would have limited general personal jurisdiction by statute, but it never did.

Finally, as discussed above, by limiting general personal jurisdiction to federal causes of action, courts can be more assured that comity implications of subjecting foreign corporations to general jurisdiction of U.S. courts has been considered and weighed by Congress and the executive branch.

\section{CONCLUSION}

The U.S. Congress has allowed a cause of action for extraterritorial violations of international human rights law for over two hundred years through the Alien Tort Statute, never having amended nor restricted the statute. It has also provided causes of action for terrorism-related claims and human trafficking. Although it was never easy to assert general personal jurisdiction over a foreign corporation even under International Shoe, the U.S. Supreme Court's move to restrictive personal jurisdiction over transnational businesses in Goodyear and Daimler greatly impedes victims of human rights-related violations from seeking and obtaining remedies pursuant to these Congressionally-provided causes of action. Such restrictions mean less access to remedy for victims of human rights abuses, even as transnational businesses gain enormous financial benefits

324. See supra note 185 .

325. See supra note 186 .

326. See supra note 24. 
from transnational operations, typically at the expense of victims in developing countries with weak judicial systems that host such businesses. Moreover, these restrictions are unfair given how transnational business is structured and operates in the modern world. Given this unfairness, Congress should act to ensure courts have personal jurisdiction over transnational businesses doing business in the United States so that victims can pursue causes of action for extraterritorial conduct that Congress has, in its wisdom, provided. Europe and Canada should take similar action, but such action is especially critical in the United States, where victims can more easily seek and obtain remedies for such harms. Moreover, such jurisdictional expansion would create an even playing field for all transnational businesses operating throughout the world, several of whom do substantial business in the United States.

Current jurisdictional rules are simply no match for the complex manner in which transnational businesses are structured and operate. Countries where transnational businesses operate need to develop true transnational jurisdictional rules. Congress enacting a broad general personal jurisdiction statute is a first, but important, step in this direction. 
